\title{
Permanent, Sex-Selective Effects of Prenatal or Adolescent Nicotine Exposure, Separately or Sequentially, in Rat Brain Regions: Indices of Cholinergic and Serotonergic Synaptic Function, Cell Signaling, and Neural Cell Number and Size at 6 Months of Age
}

\author{
Theodore A Slotkin*,', Emiko A MacKillop', Charles L Rudder', lan T Ryde', Charlotte A Tate' and \\ Frederic J Seidler'
}

'Department of Pharmacology and Cancer Biology, Duke University Medical Center, Durham, NC, USA

\begin{abstract}
Nicotine is a neuroteratogen that disrupts neurodevelopment and synaptic function, with vulnerability extending into adolescence. We assessed the permanence of effects in rats on indices of neural cell number and size, and on acetylcholine and serotonin (5HT) systems, conducting assessments at 6 months of age, after prenatal nicotine exposure, adolescent exposure, or sequential exposure in both periods. For prenatal nicotine, indices of cell number and size showed few abnormalities by 6 months, but there were persistent deficits in cerebrocortical choline acetyltransferase activity and hemicholinium-3 binding to the presynaptic choline transporter, a pattern consistent with cholinergic hypoactivity; these effects were more prominent in males than females. The expression of $5 \mathrm{HT}$ receptors also showed permanent effects in males, with suppression of the $5 \mathrm{HT}_{\text {IA }}$ subtype and upregulation of $5 \mathrm{HT}_{2}$ receptors. In addition, cell signaling through adenylyl cyclase showed heterologous uncoupling of neurotransmitter responses. Nicotine exposure in adolescence produced lasting effects that were similar to those of prenatal nicotine. However, when animals were exposed to prenatal nicotine and received nicotine subsequently in adolescence, the adverse effects then extended to females, whereas the net effect in males was similar to that of prenatal nicotine by itself. Our results indicate that prenatal or adolescent nicotine exposure evoke permanent changes in synaptic function that transcend the recovery of less-sensitive indices of structural damage; further, prenatal exposure sensitizes females to the subsequent adverse effects of adolescent nicotine, thus creating a population that may be especially vulnerable to the lasting behavioral consequences of nicotine intake in adolescence.
\end{abstract}

Neuropsychopharmacology (2007) 32, I082- 1097. doi:I0. I038/sj.npp. I 301231; published online I8 October 2006

Keywords: acetylcholine; adolescence; neural cell development; nicotine; serotonin; sex differences

\section{INTRODUCTION}

There is substantial agreement that nicotine is a neuroteratogen that alters patterns of neural cell replication, differentiation, synaptogenesis, and synaptic function in the developing brain (Levin and Slotkin, 1998; Slikker et al, 2005; Slotkin, 1998, 1999, 2004), thus contributing in a major way to the long-term liabilities associated with maternal smoking during pregnancy (Ernst et al, 2001;

* Correspondence: Dr TA Slotkin, Department of Pharmacology and Cancer Biology, Duke University Medical Center, Box 3813 DUMC, Rm CI62 LSRC - Research Dr, Durham, NC 277I0, USA, Tel: + I 919 68I 8015, Fax: + I919684 8197, E-mail: t.slotkin@duke.edu Received 26 June 2006; revised 8 August 2006; accepted II August 2006

Online publication: 15 September 2006 at http://www.acnp.org/ citations/Npp09 I506060422/default.pdf
Hellstrom-Lindahl and Nordberg, 2002; Wakschlag et al, 2002; Weissman et al, 1999; Weitzman et al, 2002). Brain development continues into adolescence and recent work indicates that many of the mechanisms by which nicotine adversely affects the fetus still operate in the adolescent brain, producing similar (albeit lesser) functional anomalies and even outright neurotoxicity (Slotkin, 2002). In addition, the adolescent brain is much more responsive to nicotine than is the adult, enhancing the synaptic and behavioral responses that contribute to dependence and addiction (Abreu-Villaça et al, 2003a-c; Collins et al, 2004; Elliott et al, 2005; Faraday et al, 2001; Slotkin, 2002), echoing observations made in adolescent smokers (DiFranza et al, 2000, 2002a,b). Furthermore, the synaptic alterations evoked by fetal nicotine exposure affect the response to nicotine in adolescence (Abreu-Villaça et al, 2004a,b; Jacobsen et al, 
2006; Slotkin et al, 2006), likely contributing to the subpopulation in the offspring of smokers that are especially vulnerable to nicotine dependence (Jacobsen et al, 2006; Kandel et al, 1994; Niaura et al, 2001; Porath and Fried, 2005; Roberts et al, 2005).

The neurochemical and morphological substrates that underlie the developmental neurotoxicity of nicotine in the fetus and adolescent have been defined primarily over a course spanning the period of nicotine exposure and withdrawal, ranging up to young adulthood (Levin and Slotkin, 1998; Slikker et al, 2005; Slotkin, 1998, 1999, 2004). Nevertheless, it is now evident that neurogenesis and neural plasticity persist into adulthood (Altman and Bayer, 1990; Bayer, 1983; Bayer et al, 1982; Huttenlocher, 1990; McWilliams and Lynch, 1983; Scheetz and ConstantinePaton, 1994) and drugs can elicit 'developmental' effects even at this late stage (Grote et al, 2005). Accordingly, the current study addresses the permanence of the cellular and synaptic anomalies evoked in rats given prenatal or adolescent nicotine exposure, or given sequential exposure in both prenatal and adolescent stages, as reflected by measurements at 6 months of age. We utilized established treatment regimens that deliver nicotine continuously throughout pregnancy or adolescence, achieving plasma nicotine concentrations comparable to that in smokers (Slikker et al, 2005; Slotkin, 1992, 1998, 2002, 2004). Our evaluations made use of families of biomarkers that typify cell number and size, acetylcholine (ACh) and serotonin (5HT) synaptic function and transsynaptic cell signaling, as established in earlier work with prenatal or adolescent nicotine exposure (Abreu-Villaça et al, 2003c, 2004b; Muneoka et al, 2001; Navarro et al, 1989; Slotkin et al, 1987; Trauth et al, 2000a, b; Xu et al, 2001, 2002; Zahalka et al, 1992; Zhu et al, 2000). First, we assessed the impact on neural cell number and size by measurements of DNA and cell protein fractions. As each neural cell contains only a single nucleus (Winick and Noble, 1965), the DNA content (amount of DNA in each brain region) reflects the total number of cells and the DNA concentration (DNA per unit tissue weight) reflects the cell-packing density (Bell et al, 1987; Slotkin et al, 1984; Winick and Noble, 1965). The ratio of total protein/DNA rises with growth and thus reflects average cell size (Qiao et al, 2003, 2004; Slotkin et al, 2005), whereas the relative proportion of membrane/total protein reflects membrane complexity associated with neural connectivity, which climbs with the increase in formation of the neuropil.

For ACh systems, we assessed choline acetyltransferase activity (ChAT) and the binding of $\left[{ }^{3} \mathrm{H}\right]$ hemicholinium-3 (HC3) to the high-affinity presynaptic choline transporter. ChAT is a constitutive marker for ACh nerve terminals, whereas HC3 binding is responsive to neuronal activity (Aubert et al, 1996; Happe and Murrin, 1992; Klemm and Kuhar, 1979; Navarro et al, 1989; Simon et al, 1976; Slotkin et al, 1990; Zahalka et al, 1992, 1993), so that comparative changes in the two markers permit distinction between effects on synaptic outgrowth as distinct from synaptic activity. We also evaluated effects on nicotinic ACh receptors (nAChRs), focusing on the $\alpha 4 \beta 2 \mathrm{nAChR}$, the predominant subtype in mammalian brain (Flores et al, 1992) and one which shows differential sensitivity to nicotine in the adolescent $v s$ the adult (Trauth et al, 1999a). For 5HT synapses, we assessed ligand binding for $5 \mathrm{HT}_{1 \mathrm{~A}}$ and $5 \mathrm{HT}_{2}$ receptors and the presynaptic $5 \mathrm{HT}$ transporter. The two receptors converge on common end points in 5HT cell signaling (Barnes and Sharp, 1999; Morin et al, 1992; Rovescalli et al, 1993) and are key players in 5HT-related mental disorders (Arango et al, 2001; Fujita et al, 2000; Yatham et al, 1999, 2000); the 5HT transporter regulates the synaptic concentration of 5HT and is the major target for antidepressant drugs (Maes and Meltzer, 1995; Nemeroff, 1998; Nutt, 2002). These three proteins have been evaluated previously for short-term changes evoked by adolescent nicotine treatment (Xu et al, 2001, 2002). Finally, we evaluated cell signaling mediated through adenylyl cyclase (AC), a pathway known to be targeted by both prenatal and adolescent nicotine treatments (Slotkin et al, 1992, 2006; Xu et al, 2002). We focused on assessments of basal AC activity, the maximal response capability evoked by a direct $\mathrm{AC}$ stimulant, forskolin, and the ability of a neurotransmitter receptor coupled to AC activation, the $\beta$-adrenergic receptor ( $\beta \mathrm{AR})$ to stimulate AC.

\section{METHODS}

\section{Animals and Nicotine Infusions}

All studies were carried out with the approval of the Duke University Institutional Animal Care and Use Committee, in accordance with the declaration of Helsinki principle and with the Guide for the Care and Use of Laboratory Animals as adopted and promulgated by the National Institutes of Health. Timed-pregnant Sprague-Dawley rats were shipped on gestational day 2 by climate-controlled truck (total transit time $<1 \mathrm{~h}$ ), housed individually and allowed free access to food and water. There were four treatment groups: controls (prenatal vehicle + adolescent vehicle), prenatal nicotine exposure (prenatal nicotine + adolescent vehicle), adolescent nicotine exposure (prenatal vehicle + adolescent nicotine), and those receiving the combined treatment (prenatal nicotine + adolescent nicotine). On gestational day 4 , before implantation of the embryo in the uterine wall, each animal was quickly anesthetized with ether, a $3 \times 3 \mathrm{~cm}$ area on the back was shaved, and an incision made to permit s.c. insertion of type 2ML2 Alzet osmotic minipumps. Pumps were prepared with nicotine bitartrate dissolved in bacteriostatic water, to deliver an initial dose rate of $6 \mathrm{mg} / \mathrm{kg}$ of nicotine (calculated as free base) per day. The incision was closed with wound clips and the animals were permitted to recover in their home cages. Control animals were implanted with minipumps containing only the water and an equivalent concentration of sodium bitartrate, adjusted to the same $\mathrm{pH}(6.0)$ as the nicotine bitartrate solution. It should be noted that the pump, marketed as a 2-week infusion device, actually takes 17.5 days to be exhausted completely (information supplied by the manufacturer) and thus the nicotine infusion terminates during gestational day 21. Maternal plasma nicotine levels achieved with this administration model resemble those seen in heavy smokers $(25-60 \mathrm{ng} / \mathrm{ml})$ as characterized previously (Isaac and Rand, 1972; Levin and Slotkin, 1998; Lichtensteiger et al, 1988; Murrin et al, 1985; Slotkin, 1992, 1998, 1999, 2004). This animal model also resembles the effects of maternal smoking in that fetal nicotine levels 
exceed those found in maternal plasma (Luck et al, 1985; Sarasin et al, 2003).

Parturition occurred during gestational day 22, which was also taken as postnatal day 0 . After birth, pups were randomized within treatment groups and litter sizes were culled to 10 (five males and five females) to ensure standard nutrition. Randomization was repeated every few days to distribute differential effects of maternal caretaking equally among all litters; cross-fostering, by itself, has no impact on neurochemical or behavioral effects of nicotine exposure (Ribary and Lichtensteiger, 1989). Animals were weaned on postnatal day 21 .

On postnatal day 30, each animal was implanted with a minipump (Alzet type 1002) as already described, again set to deliver either vehicle or nicotine at an initial dose rate of $6 \mathrm{mg} / \mathrm{kg} / \mathrm{day}$, with the infusion terminating during postnatal day 47 (Slotkin, 1998; Trauth et al, 1999b, 2000b). The nicotine exposure period thus spans the recognized boundaries of adolescence in the rat, as typified by endocrine, pubertal and behavioral parameters (Spear, 2000). In the adolescent rat, this paradigm produces plasma nicotine levels of $25 \mathrm{ng} / \mathrm{ml}$, similar to that in typical smokers (Lichtensteiger et al, 1988; Trauth et al, 2000b). Studies were then conducted at 6 months of age (postnatal day 180), more than 4 months after the termination of adolescent nicotine treatment. For each treatment group, 12 animals were examined, equally divided into males and females, with each litter of origin contributing no more than one male and one female to any of the determinations.

Animals were decapitated and the brain was dissected into cerebral cortex, striatum, hippocampus, midbrain, brainstem, and cerebellum (Trauth et al, 2000b), and the cerebral cortex was then divided down the midline to separate left and right hemispheres. Tissues were flashfrozen in liquid nitrogen and stored at $-45^{\circ} \mathrm{C}$ until assayed. The hippocampus, striatum, midbrain, and left half of the cerebral cortex were used for biomarkers of cell number and size and for ACh biomarkers, whereas the brainstem and right half of the cerebral cortex were evaluated for $5 \mathrm{HT}$ and AC biomarkers. Because the cerebellum is sparse in both ACh and 5HT projections but has a high norepinephrine concentration, this region was used for assessment of $\mathrm{AC}$ signaling and also for $\beta \mathrm{AR}$ binding.

\section{Biomarkers of Neural Cell Number and Size}

Each tissue was thawed and homogenized (Polytron, Brinkmann Instruments, Westbury, NY) in ice-cold $10 \mathrm{mM}$ sodium-potassium phosphate buffer ( $\mathrm{pH} 7.4)$ and aliquots of the homogenate were withdrawn for measurement of DNA and total protein. DNA was assessed with a modified (Trauth et al, 2000b) fluorescent dye-binding method (Labarca and Piagen, 1980). Aliquots were diluted in $50 \mathrm{mM}$ sodium phosphate, $2 \mathrm{M} \mathrm{NaCl}, 2 \mathrm{mM}$ EDTA ( $\mathrm{pH}$ 7.4) and sonicated briefly (Virsonic Cell Disrupter, Virtis, Gardiner, NY). Hoechst 33258 was added to a final concentration of $1 \mu \mathrm{g} / \mathrm{ml}$. Samples were then read in a spectrofluorometer using an excitation wavelength of $356 \mathrm{~nm}$ and an emission wavelength of $458 \mathrm{~nm}$, and were quantitated using standards of purified DNA. The total concentration of tissue proteins was assayed from the original homogenate spectrophotometrically with bicin- choninic acid (Smith et al, 1985); in addition, we assessed the concentration of membrane proteins from the membrane preparations used for radioligand binding, as described below.

\section{ACh Biomarkers}

Aliquots of the same homogenate used for DNA determinations were assayed in duplicate for ChAT using established procedures (Lau et al, 1988; Qiao et al, 2003, 2004). Each tube contained final concentrations of $60 \mathrm{mM}$ sodium phosphate ( $\mathrm{pH} 7.9$ ), $200 \mathrm{mM} \mathrm{NaCl}, 20 \mathrm{mM}$ choline chloride, $17 \mathrm{mM} \mathrm{MgCl} 2,1 \mathrm{mM}$ EDTA, $0.2 \%$ Triton X-100, $0.12 \mathrm{mM}$ physostigmine, $0.6 \mathrm{mg} / \mathrm{ml}$ bovine serum albumin, and $50 \mu \mathrm{M}\left[{ }^{14} \mathrm{C}\right]$ acetyl-coenzyme A. Blanks contained homogenization buffer instead of the tissue homogenate. Samples were preincubated for $15 \mathrm{~min}$ on ice, transferred to a $37^{\circ} \mathrm{C}$ water bath for $30 \mathrm{~min}$, and the reaction terminated by placing the samples on ice. Labeled ACh was then extracted, counted and the activity determined relative to tissue protein (Smith et al, 1985). Preliminary determinations established that enzyme activity was linear with time and tissue concentration under these conditions.

For measurements of HC3 binding, an aliquot of the same tissue homogenate was sedimented at $40000 \mathrm{~g}$ for $15 \mathrm{~min}$ and the supernatant solution was discarded. The membrane pellet was resuspended (Polytron) in the original volume of buffer, resedimented, and the resultant pellet was resuspended using a smooth glass homogenizer fitted with a Teflon pestle, in $10 \mathrm{mM}$ sodium-potassium phosphate buffer (pH 7.4) containing $150 \mathrm{mM} \mathrm{NaCl}$. An aliquot was withdrawn for the determination of membrane protein (Smith et al, 1985) and radioligand binding was evaluated with $2 \mathrm{nM}\left[{ }^{3} \mathrm{H}\right] \mathrm{HC} 3$ (Vickroy et al, 1984), with incubation for $20 \mathrm{~min}$ at room temperature, followed by rapid vacuum filtration onto glass fiber filters (presoaked for $30 \mathrm{~min}$ with $0.15 \%$ polyethyleneimine in buffer). The nonspecific component was defined as radioligand binding in the presence of an excess concentration of unlabeled HC3 $(10 \mu \mathrm{M})$ and binding values were expressed relative to membrane protein. For nAChR binding, each assay contained a final concentration of $1 \mathrm{nM}\left[{ }^{3} \mathrm{H}\right]$ cytisine in a total volume of $250 \mu \mathrm{l}$ of a buffer consisting of $120 \mathrm{mM}$ $\mathrm{NaCl}, 5 \mathrm{mM} \mathrm{KCl}, 2.5 \mathrm{mM} \mathrm{CaCl}_{2}, 1 \mathrm{mM} \mathrm{MgCl} \mathrm{Mg}_{2}$, and $50 \mathrm{mM}$ Tris (pH 7.4). Incubations lasted $75 \mathrm{~min}$ at $4{ }^{\circ} \mathrm{C}$, with or without $10 \mu \mathrm{M}$ nicotine to displace specific binding.

\section{HT Biomarkers}

Brain regions used for 5HT biomarkers were thawed and homogenized (Polytron) in ice-cold $50 \mathrm{mM}$ Tris ( $\mathrm{pH}$ 7.4) and the cell membrane fraction was prepared by differential sedimentation as already described, with final resuspension in Tris buffer. As before, an aliquot was withdrawn for the determination of membrane protein (Smith et al, 1985). Two radioligands were used to determine 5HT receptor binding (Xu et al, 2002): $1 \mathrm{nM}\left[{ }^{3} \mathrm{H}\right] 8$-hydroxy-2-(di-npropylamino)tetralin for $5 \mathrm{HT}_{1 \mathrm{~A}}$ receptors (Park et al, 1999; Stockmeier et al, 1998), and $0.4 \mathrm{nM}\left[{ }^{3} \mathrm{H}\right]$ ketanserin for $5 \mathrm{HT}_{2}$ receptors (Leysen et al, 1982; Park et al, 1999). For $5 \mathrm{HT}_{1 \mathrm{~A}}$ receptors, incubations lasted for $30 \mathrm{~min}$ at $25^{\circ} \mathrm{C}$ in a buffer consisting of $50 \mathrm{mM}$ Tris (pH 8), $2 \mathrm{mM} \mathrm{MgCl}_{2}$, and 
$2 \mathrm{mM}$ sodium ascorbate; $100 \mu \mathrm{M} 5 \mathrm{HT}$ was used to displace specific binding. For $5 \mathrm{HT}_{2}$ receptors, incubations lasted $15 \mathrm{~min}$ at $37^{\circ} \mathrm{C}$ in $50 \mathrm{mM}$ Tris ( $\mathrm{pH} \mathrm{7.4)}$ ) and specific binding was displaced with $10 \mu \mathrm{M}$ methylsergide. For binding to the presynaptic 5HT transporter (Moret and Briley, 1991; Slotkin et al, 1997, 1999, 2000; Xu et al, 2001), the membrane suspension was incubated with $85 \mathrm{pM}\left[{ }^{3} \mathrm{H}\right]$ paroxetine with or without addition of $100 \mu \mathrm{M} 5 \mathrm{HT}$ to displace specific binding, and incubations lasted $120 \mathrm{~min}$ at $20^{\circ} \mathrm{C}$.

\section{AC Signaling}

For AC determinations, the cell membrane fraction was resuspended in a buffer consisting of $125 \mathrm{mM}$ sucrose, $6 \mathrm{mM} \mathrm{MgCl}_{2}$, and $50 \mathrm{mM}$ Tris- $\mathrm{HCl}$ ( $\mathrm{pH} \mathrm{7.5).} \mathrm{AC} \mathrm{assessments}$ were conducted by standard techniques published previously (Auman et al, 2000, 2001; Zeiders et al, 1997, 1999). Briefly, aliquots were incubated for $10 \mathrm{~min}$ at $30^{\circ} \mathrm{C}$ with final concentrations of $100 \mathrm{mM}$ Tris- $\mathrm{HCl}(\mathrm{pH}$ 7.4), $10 \mathrm{mM}$ theophylline, $1 \mathrm{mM}$ ATP, $2 \mathrm{mM} \mathrm{MgCl}_{2}, 1 \mathrm{mg} / \mathrm{ml}$ bovine serum albumin, and a creatine phosphokinase-ATP-regenerating system consisting of $10 \mathrm{mM}$ sodium phosphocreatine and $8 \mathrm{IU} / \mathrm{ml}$ phosphocreatine kinase, with $10 \mu \mathrm{M}$ GTP in a total volume of $250 \mu \mathrm{l}$. The enzymatic reaction was stopped by placing the samples in a $90-100^{\circ} \mathrm{C}$ water bath for $5 \mathrm{~min}$, followed by sedimentation at $3000 \mathrm{~g}$ for $15 \mathrm{~min}$, and the supernatant solution was assayed for cAMP using radioimmunoassay kits. Preliminary experiments showed that the enzymatic reaction was linear well beyond the assay period and was linear with membrane protein concentration; concentrations of cofactors were optimal and, in particular, higher concentrations of GTP produced no further augmentation of activity.

AC activity was evaluated in several different ways. First, we measured basal AC activity without addition of any stimulants. Next, we assessed the maximal response to a direct AC stimulant, forskolin $(100 \mu \mathrm{M})$ (Limbird and Macmillan, 1981; Seamon and Daly, 1986). Finally, in the cerebellum (where we measured $\beta \mathrm{AR}$ binding, we determined the $\mathrm{AC}$ response to a $\beta \mathrm{AR}$ agonist, $100 \mu \mathrm{M}$ isoproterenol, as both absolute $\mathrm{AC}$ activity and as a ratio to total activity (isoproterenol/forskolin ratio). The chosen concentrations of each stimulant produce maximal responses, as assessed in earlier studies (Auman et al, 2000, 2001; Zeiders et al, 1997, 1999).

In the cerebellum, the membrane preparation obtained for AC determinations was also used to evaluate $\beta \mathrm{AR}$ binding. Aliquots were incubated with $67 \mathrm{pM}\left[{ }^{125} \mathrm{I}\right]$ iodopindolol in $145 \mathrm{mM} \mathrm{NaCl}, 2 \mathrm{mM} \mathrm{MgCl}, 1 \mathrm{mM} \mathrm{Na}$ ascorbate, $20 \mathrm{mM}$ Tris ( $\mathrm{pH} \mathrm{7.5),} \mathrm{for} 20 \mathrm{~min}$ at room temperature in a total volume of $250 \mu \mathrm{l}$. Displacement of nonspecific binding was evaluated with $100 \mu \mathrm{M} d, l$-isoproterenol.

\section{Data Analysis}

Data are presented as means and standard errors. Differences between groups were first assessed by a global ANOVA (data log-transformed because of heterogeneous variance), incorporating all factors: prenatal treatment, adolescent treatment, brain region, and sex. This initial test was conducted across related measurements (considered as repeated measures, as they were all derived from the same homogenate) corresponding to each index class: indices of cell number (DNA concentration and content) and size (total protein/DNA, membrane/total protein), ACh biomarkers (ChAT, HC3 binding, HC3/ChAT ratio, nAChR binding), $5 \mathrm{HT}$ biomarkers $\left(5 \mathrm{HT}_{1 \mathrm{~A}}\right.$ and $5 \mathrm{HT}_{2}$ receptors, and $5 \mathrm{HT}$ transporter binding), and the multiple AC measures. Depending on the treatment interactions obtained in the global tests, data were then subdivided for lower order ANOVAs, followed where appropriate, by Fisher's protected least significant difference to establish effects comparing individual groups. However, where treatment effects were not interactive with other variables, only the main effects are shown without lower-order tests of individual differences. Significance for main treatment effects was assumed at $p<0.05$, but for interactions at $p<0.1$, we also examined whether lower order main effects were detectable after subdivision of the interactive variables (Snedecor and Cochran, 1967). For convenience, some data are presented as the percentage change from control values, however, statistical evaluations were always carried out on the original data. For reference, control values appear in Table 1.

The study design required two different ways of regarding treatment variables. To compare the effects of prenatal exposure alone, adolescent exposure, or the combined exposure to controls or to each other, the four treatment groups were considered as a one-dimensional factor in the statistical design. To determine whether the effects of prenatal exposure and adolescent exposure were interactive, the treatment factors were changed to a two-dimensional design. In this formulation, more-than-additive (synergistic) and less-than-additive effects appear as significant interactions between the two treatment dimensions, whereas simple, additive effects do not show significant interactions.

\section{Materials}

Animals were obtained from Charles River (Raleigh, NC) and Alzet minipumps from Durect Corp. (Cupertino, CA). Bacteriostatic water used for the minipump solutions came from Abbott Laboratories (N Chicago, IL) and methylsergide was purchased from Sandoz Pharmaceuticals, E Hanover, NJ). PerkinElmer Life Sciences (Boston, MA) was the source for radioisotopically-labeled compounds: $\left[{ }^{14} \mathrm{C}\right]$ acetyl-coenzyme A (specific activity $60 \mathrm{mCi} / \mathrm{mmol}$, diluted with unlabeled compound to $6.7 \mathrm{mCi} / \mathrm{mmol})$, $\left[{ }^{3} \mathrm{H}\right] \mathrm{HC} 3 \quad(125 \mathrm{Ci} / \mathrm{mmol}), \quad\left[{ }^{3} \mathrm{H}\right] 8$-hydroxy-2-(di-n-propylamino)tetralin $(135 \mathrm{Ci} / \mathrm{mmol}),\left[{ }^{3} \mathrm{H}\right]$ ketanserin $(63 \mathrm{Ci} / \mathrm{mmol})$, $\left[{ }^{3} \mathrm{H}\right]$ paroxetine $(19.4 \mathrm{Ci} / \mathrm{mmol}),\left[{ }^{3} \mathrm{H}\right]$ cytisine $(35 \mathrm{Ci} / \mathrm{mmol})$, and $\left[{ }^{125} \mathrm{I}\right]$ iodopindolol $(2200 \mathrm{Ci} / \mathrm{mmol})$. Radioimmunoassay kits for the determination of cAMP were obtained from Amersham Biosciences (Piscataway, NJ). All other chemicals were purchased from Sigma Chemical Co. (St Louis, MO).

\section{RESULTS}

\section{Biomarkers of Neural Cell Number and Size}

Neither prenatal nor adolescent nicotine exposure, separately or in combination, elicited significant deficits in body weight or brain region weights (data not shown). 
Table I Control Values

\begin{tabular}{|c|c|c|c|c|c|c|c|c|c|c|c|c|}
\hline & \multicolumn{2}{|c|}{ Cerebral cortex } & \multicolumn{2}{|c|}{ Hippocampus } & \multicolumn{2}{|c|}{ Striatum } & \multicolumn{2}{|c|}{ Midbrain } & \multicolumn{2}{|c|}{ Brainstem } & \multicolumn{2}{|c|}{ Cerebellum } \\
\hline & Male & Female & Male & Female & Male & Female & Male & Female & Male & Female & Male & Female \\
\hline \multicolumn{13}{|l|}{ Cell number and size } \\
\hline DNA concentration ( $\mu \mathrm{g} / \mathrm{g}$ tissue) & $717 \pm 12$ & $737 \pm 22$ & $582 \pm 7$ & $648 \pm 13^{*}$ & $557 \pm 14$ & $602 \pm 39$ & $720 \pm 11$ & $753 \pm 13$ & & & & \\
\hline DNA content ( $\mu \mathrm{g} /$ region $)$ & $344 \pm 14$ & $320 \pm 7$ & $74 \pm 3$ & $77 \pm 1$ & $66 \pm 2$ & $64 \pm 2$ & $258 \pm 6$ & $243 \pm 6$ & & & & \\
\hline Total protein/DNA $(\mu \mathrm{g} / \mu \mathrm{g})$ & $|2| \pm 3$ & $119 \pm 2$ & $150 \pm 2$ & $142 \pm 3$ & $148 \pm 5$ & $150 \pm 4$ & $124 \pm 4$ & $110 \pm 3^{*}$ & & & & \\
\hline$\%$ Membrane/total protein $(\mu \mathrm{g} / \mu \mathrm{g})$ & $44 \pm 1$ & $42 \pm 1$ & $41 \pm 1$ & $39 \pm 2$ & $46 \pm 1$ & $45 \pm 1$ & $44 \pm 2$ & $48 \pm 1$ & & & & \\
\hline \multicolumn{13}{|l|}{ ACh markers } \\
\hline Choline acetyltransferase (pmol/min/mg protein) & $1050 \pm 25$ & $1055 \pm 24$ & $1026 \pm 13$ & $1068 \pm 33$ & $2666 \pm 49$ & $2865 \pm 74 *$ & $845 \pm 32$ & $949 \pm 13 *$ & & & & \\
\hline HC3 binding (fmol/mg protein) & $23.8 \pm 2.4$ & $20.6 \pm 0.6$ & $13.5 \pm 0.6$ & $14.6 \pm 0.4$ & $5 I \pm 2$ & $58 \pm 2$ & $12.4 \pm 0.3$ & $12.2 \pm 0.4$ & & & & \\
\hline HC3/ChAT (ratio × 1000) & $23.6 \pm 2.2$ & $19.5 \pm 0.7$ & $13.3 \pm 0.8$ & $13.3 \pm 0.5$ & $19.1 \pm 0.9$ & $20.2 \pm 0.9$ & $14.9 \pm 0.7$ & $12.9 \pm 0.2 *$ & & & & \\
\hline nAChR binding (fmol/mg protein) & $62 \pm 2$ & $65 \pm 1$ & $28 \pm 1$ & $29 \pm 1$ & $77 \pm 1$ & $77 \pm 2$ & $66 \pm 1$ & $69 \pm 1$ & & & & \\
\hline \multicolumn{13}{|l|}{$5 H T$ markers } \\
\hline $5 H T_{\mid A}$ binding (fmol/mg protein) & $60 \pm 1$ & $68 \pm 2 *$ & & & & & & & $28 \pm 2$ & $28 \pm 1$ & & \\
\hline $5 \mathrm{HT}_{2}$ binding (fmol/mg protein) & $109 \pm 7$ & $|3| \pm 4 *$ & & & & & & & $21 \pm 1$ & $21 \pm 1$ & & \\
\hline 5HT transporter binding (fmol/mg protein) & $523 \pm 10$ & $588 \pm 14 *$ & & & & & & & $344 \pm 18$ & $371 \pm 10$ & & \\
\hline \multicolumn{13}{|l|}{ Adenylyl cyclase } \\
\hline Basal (pmol/min/mg protein) & $197 \pm 2$ & $202 \pm 3$ & & & & & & & $156 \pm 6$ & $135 \pm 8$ & $269 \pm 14$ & $248 \pm 6$ \\
\hline Forskolin (pmol/min/mg protein) & $1236 \pm 60$ & $1236 \pm 54$ & & & & & & & $453 \pm 14$ & $470 \pm 13$ & $1425 \pm 42$ & $|47| \pm 36$ \\
\hline Isoproterenol (pmol/min/mg protein) & & & & & & & & & & & $317 \pm 16$ & $287 \pm 9$ \\
\hline$\%$ Isoproterenol/forskolin & & & & & & & & & & & $22.6 \pm 0.7$ & $19.8 \pm 1.1$ \\
\hline
\end{tabular}

*Significant difference between males and females. 

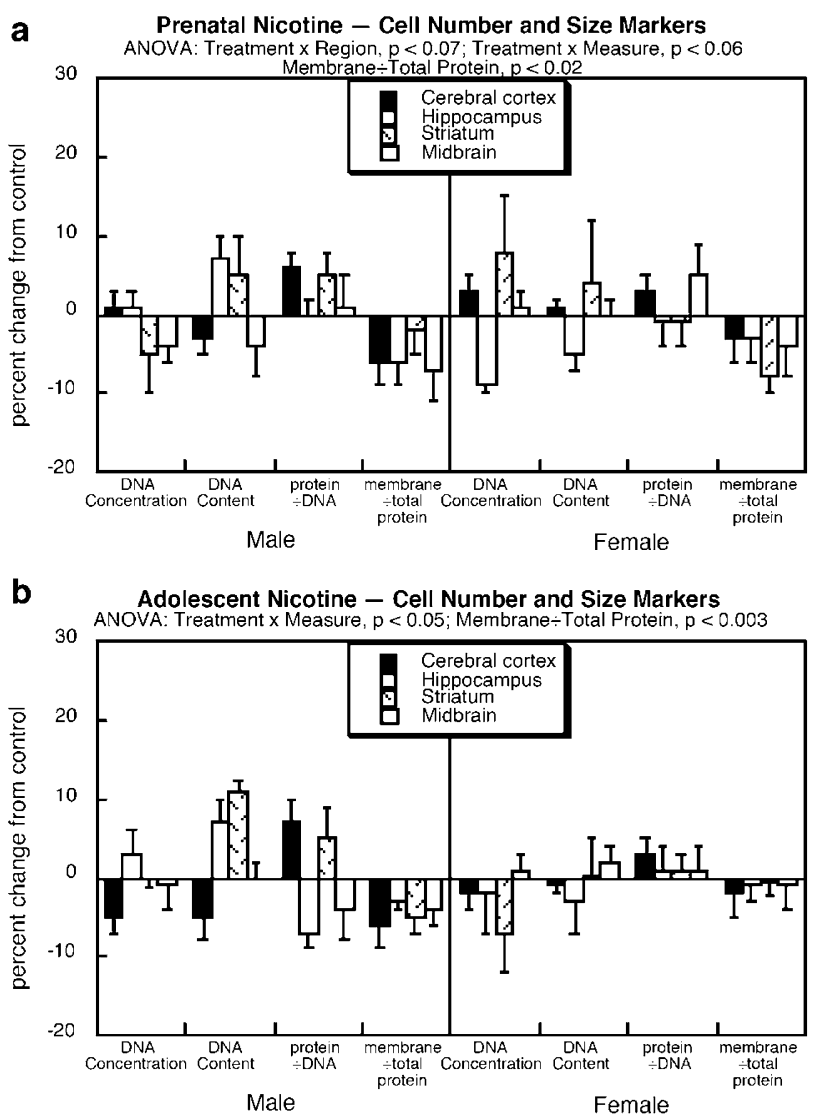

C Prenatal and Adolescent Nicotine - Cell Number and Size Markers

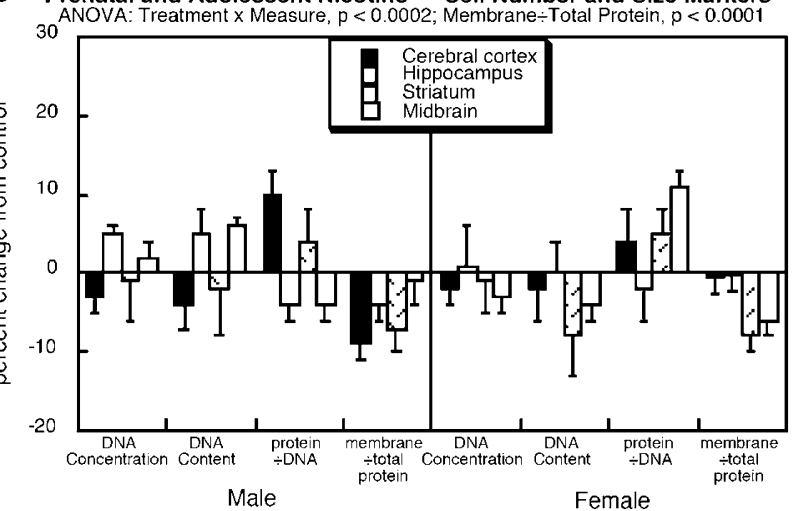

Figure I Effects of prenatal nicotine exposure (a), adolescent nicotine exposure (b), or prenatal nicotine followed by adolescent nicotine (c) on biomarkers of cell number and size. Data are shown as the percent change from the corresponding control values (Table I). ANOVA across all variables appears at the top of each panel. For each treatment paradigm, because of the absence of a treatment $\times$ sex interaction, separate statistical analyses were not conducted for males and females; the only measure showing a significant overall effect was the membrane/total protein ratio.

Nevertheless, global ANOVA across all biomarkers of neural cell number and size indicated regionally-selective effects (treatment $\times$ region, $p<0.05$ ) for specific biomarkers (treatment $\times$ measure, $p<0.03$ ). Regarding prenatal and adolescent treatments as two separate dimensions in the ANOVA design, we also found a significant prenatal nicotine $x$ adolescent nicotine $\times$ region interaction $(p<0.02)$, indicat-
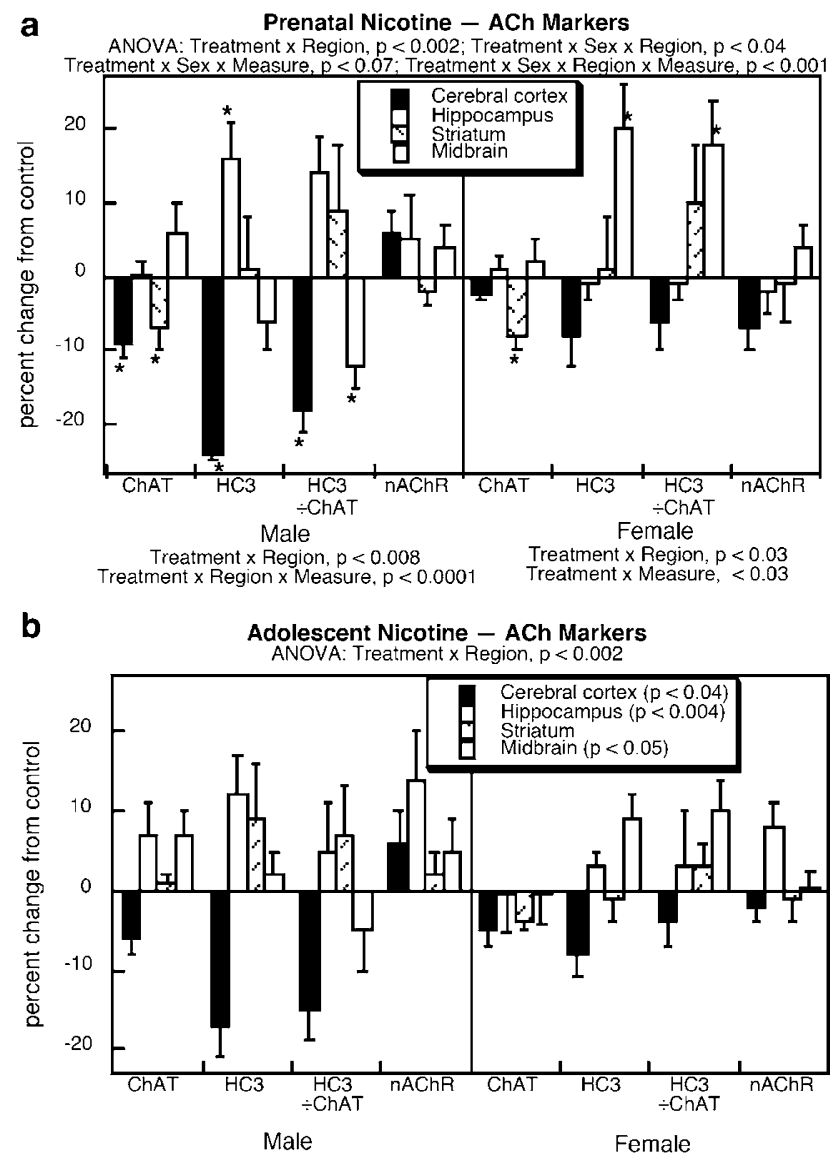

Prenatal and Adolescent Nicotine - ACh Markers
C ANOVA: Treatment $x$ Region, $p<0.0002$ Treatment $x$ Region $\times$ Measure, $p<0.006$

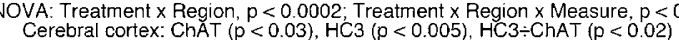

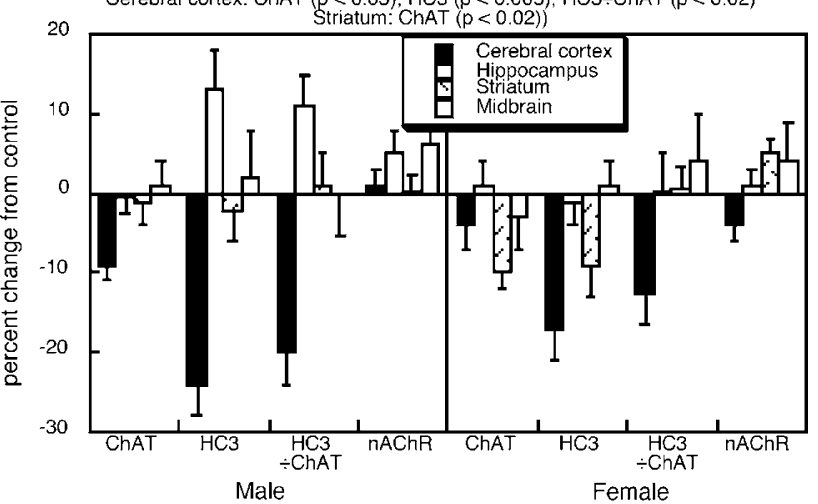

Figure 2 Effects of prenatal nicotine exposure (a), adolescent nicotine exposure (b), or prenatal nicotine followed by adolescent nicotine (c) on ACh biomarkers. Data are shown as the percent change from the corresponding control values (Table I). ANOVA across all variables appears at the top of each panel. For prenatal nicotine, because of the treatment $\times$ sex interaction, separate statistical analyses were conducted for males and females, shown at the bottom of (a); asterisks denote individual brain regions for which the specific measures in prenatal nicotine group differ from controls, as justified by the treatment $x$ region and treatment $x$ measure interactions for each sex. For adolescent nicotine, there was only a treatment $x$ region interaction so that separate analyses for each sex could not be carried out; significance for each region is shown within the panel. For the combined prenatal and adolescent treatment, the lower-order tests for each measure and region are shown at the top of the panel, without separation by sex, as justified by the interaction of treatment with those two covariables. 
ing that some of the effects of the dual treatment were not simply reflective of the summation of the two individual effects. Results were therefore subdivided into the three different types of treatments (prenatal nicotine, adolescent nicotine, prenatal + adolescent nicotine) for presentation.

Prenatal nicotine exposure had small and inconsistent effects on DNA concentration, DNA content, and the total protein/DNA ratio, but did cause a significant overall reduction in membrane/total protein, amounting to a net effect of 5-10\% (Figure 1a). Adolescent nicotine showed a similar but smaller effect (Figure $1 \mathrm{~b}$ ) and the combination of prenatal and adolescent nicotine exposure also showed a significant reduction in the ratio that was indistinguishable from that of the prenatal treatment alone (Figure 1c). The effects of the combined exposure were significantly lower than expected from the summation of the two individual effects $(p<0.05$ for the interaction of prenatal nicotine $\times$ adolescent nicotine).

\section{ACh Biomarkers}

Global ANOVA across all ACh-related measures indicated a main treatment effect of nicotine $(p<0.05)$ as well as regionally-selective effects (treatment $\times$ region, $p<0.002$ ) that differed among the various measurements (treatment $\times$ region $\times$ measure, $p<0.005)$. Regarding the prenatal and adolescent treatments as two separate dimensions in the ANOVA further indicated non-additive interactions between prenatal and adolescent nicotine exposure that varied according to region, sex and the specific $\mathrm{ACh}$ biomarker being measured: $p<0.02$ for prenatal nicotine $\times$ adolescent nicotine $\times \operatorname{sex} \times$ measure; $p<0.03$ for prenatal nicotine $\times$ adolescent nicotine $\times$ region $\times \operatorname{sex} \times$ measure. The sex differences reflected greater effects on the cerebral cortex and hippocampus in males, and lesser effects in the midbrain $(p<0.05$ for treatment $\times$ sex for each region); however, the treatment $\times$ sex interactions were not always sustained in the lower order tests, as discussed below.

Prenatal nicotine exposure led to sex-selective deficits in ACh biomarkers in the cerebral cortex (Figure 2a). In males, there were significant deficits in ChAT activity but substantially larger deficits in the biomarker of neuronal activity (HC3 binding), and accordingly, the HC3/ChAT ratio declined by nearly $20 \%$. In contrast, there was little or no change for the same parameters in the cerebral cortex of

Figure 3 Effects of prenatal nicotine exposure (a), adolescent nicotine exposure (b), or prenatal nicotine followed by adolescent nicotine (c) on $5 \mathrm{HT}$ biomarkers. Data are shown as the percent change from the corresponding control values (Table I). ANOVA across all variables appears at the top of each panel. For prenatal nicotine, because of the treatment $\times$ sex interaction, separate statistical analyses were conducted for males and females, shown at the bottom of (a); separate statistical evaluations were conducted for each measure but not for each region, in accordance with the appropriate interaction terms. For adolescent nicotine, lower order analysis for each region appears at the bottom of the panel, without separation of the different measures, in keeping with the treatment interactions with sex and region but not measure. Similarly, for the combined prenatal and adolescent treatment, the lower-order tests for each measure are shown at the bottom of the panel, as justified by the interaction of treatment with sex and measure but not region. Abbreviations: $5 \mathrm{HTT}$, $5 \mathrm{HT}$ transporter; NS, not significant. females. In the other regions, prenatal nicotine exposure showed activation of ACh pathways, evidenced by increases in HC3 binding in the hippocampus (males) or midbrain (females). There was little or no effect on nAChR binding in any of the regions.

Adolescent nicotine exposure (Figure $2 \mathrm{~b}$ ) elicited longterm changes in ACh biomarkers very similar to those of prenatal nicotine, although in this case the effects were slightly smaller and the interactions of treatment with sex and measure did not reach statistical significance in the overall ANOVA. Cerebrocortical values were significantly
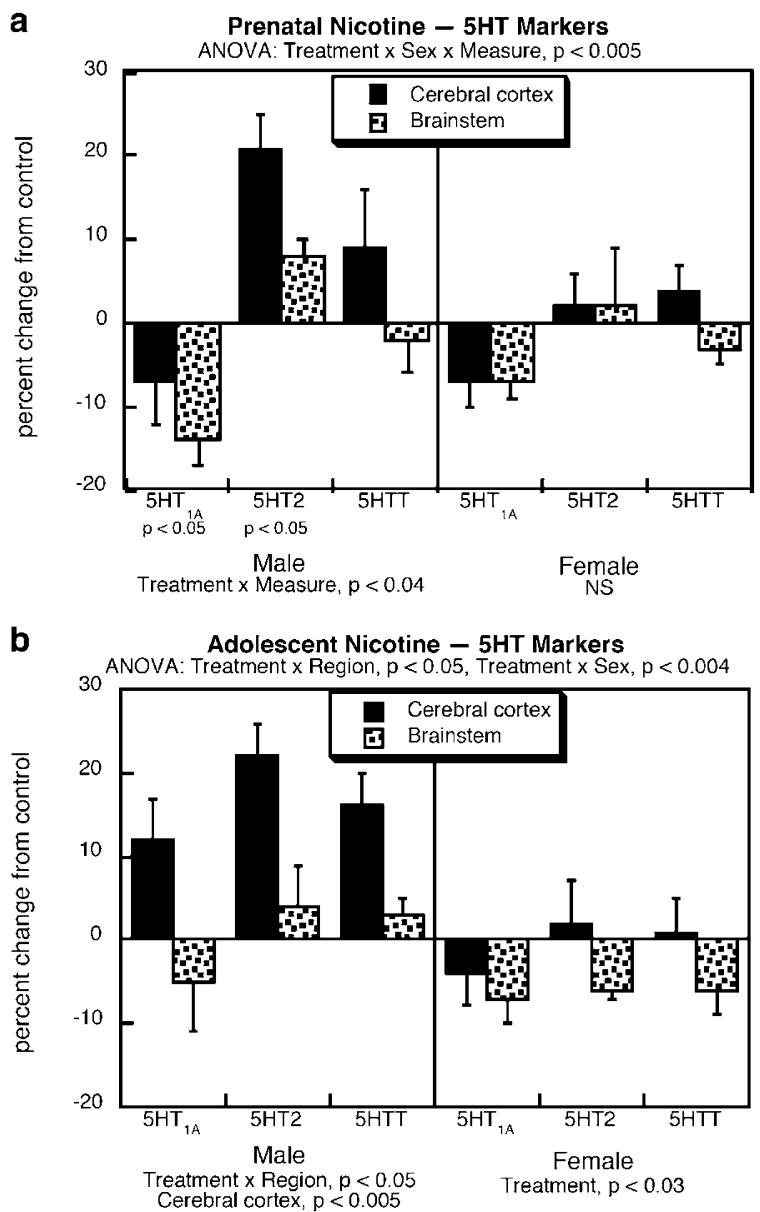

C Prenatal and Adolescent Nicotine - 5HT Markers
ANOVA

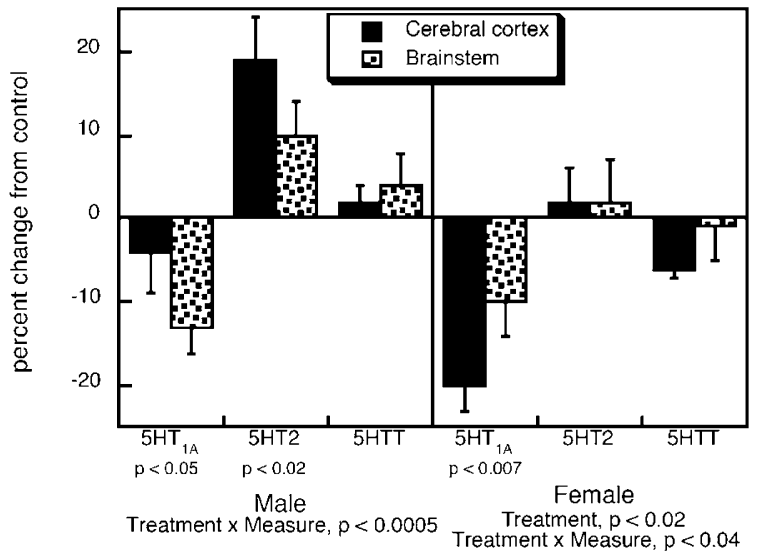


lower, whereas those in the hippocampus and midbrain were higher than in controls, showing the same trend for larger effects in males as seen with prenatal nicotine; statistical comparisons across the two treatment paradigms showed comparable sex effects, that is, the significant sex difference for prenatal nicotine was not distinguishable from the similar but nonsignificant sex difference for adolescent nicotine.

When animals exposed to prenatal nicotine were then given nicotine in adolescence, the long-term changes in cerebrocortical ACh biomarkers were the largest of all (Figure 2c), and again the same pattern was seen, characterized by suppression of ChAT and HC3, with a greater effect on the latter. To evaluate whether the net effects of the combined treatment were distinguishable from simple additivity of the two individual effects, we performed ANOVA with the two treatment paradigms considered as separate dimensions, and found a significant prenatal nicotine $\times$ adolescent nicotine $\times$ sex interaction, reflecting less-than-additive effects in males but more-than-additive effects in females. Accordingly, although males showed a significantly larger effect of separate exposure to prenatal or adolescent nicotine on cerebrocortical values, with the combined treatment, both males and females displayed pronounced deficits.

\section{HT Biomarkers}

In the global ANOVA, treatment effects on 5HT biomarkers were both sex-selective (treatment $\times$ sex, $p<0.02$ ) and regionally disparate (treatment $\times$ region, $p<0.05$ ) and also differed among the three different $5 \mathrm{HT}$ measures (treatment $\times$ measure, $p<0.0001$ ). Again, regarding prenatal and adolescent exposures as separate ANOVA dimensions revealed non-additive interactions of the two treatments (prenatal nicotine $\times$ adolescent nicotine $\times$ region, $p<0.007$ ).

Prenatal nicotine exposure elicited long-term changes in 5HT biomarkers in males but not females (Figure 3a). Whereas $5 \mathrm{HT}_{1 \mathrm{~A}}$ receptor binding was significantly reduced, $5 \mathrm{HT}_{2}$ receptors showed significant overall increases. Adolescent nicotine treatment in males elicited significant elevations in cerebrocortical values across all three 5HT biomarkers but had little effect in the brainstem (Figure $3 b$ ); again, these effects were not seen in females, who instead showed a small but statistically significant overall reduction. When animals were exposed to prenatal nicotine and then given nicotine in adolescence, the long-term effects in males were quite similar to those seen with prenatal treatment alone (Figure $3 \mathrm{c}$ ): reductions in $5 \mathrm{HT}_{1 \mathrm{~A}}$ receptor binding and increases in $5 \mathrm{HT}_{2}$ receptor binding. Using the two treatment paradigms as separate ANOVA dimensions, we found a significant prenatal nicotine $\times$ adolescent nicotine interaction $(p<0.02)$, indicative of less-than-additive effects that reflected the restriction of the net effect of combined treatment to values no greater than those seen with the prenatal treatment. For females, however, the effects on $5 \mathrm{HT}_{1 \mathrm{~A}}$ receptors were significantly enhanced by the double treatment $(p<0.05$ for prenatal nicotine $\times$ adolescent nicotine), so that whereas each of the individual treatments produced only small changes, the combined exposures produced deficits of up to $20 \%$. a

Prenatal Nicotine - Adenylyl Cyclase ANOVA: Treatment $x$ Sex, $p<0.007$;

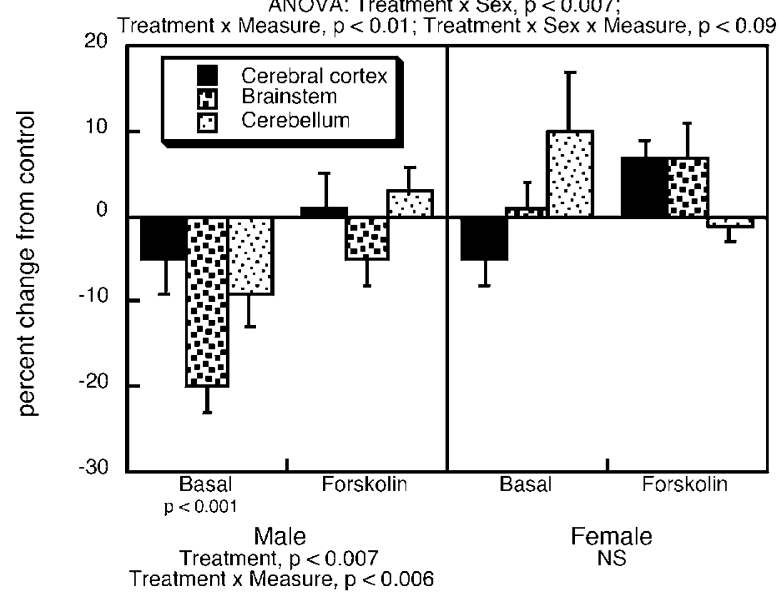

b Adolescent Nicotine - Adenylyl Cyclase ANOVA: Treatment $x$ Measure, $p<0.000$

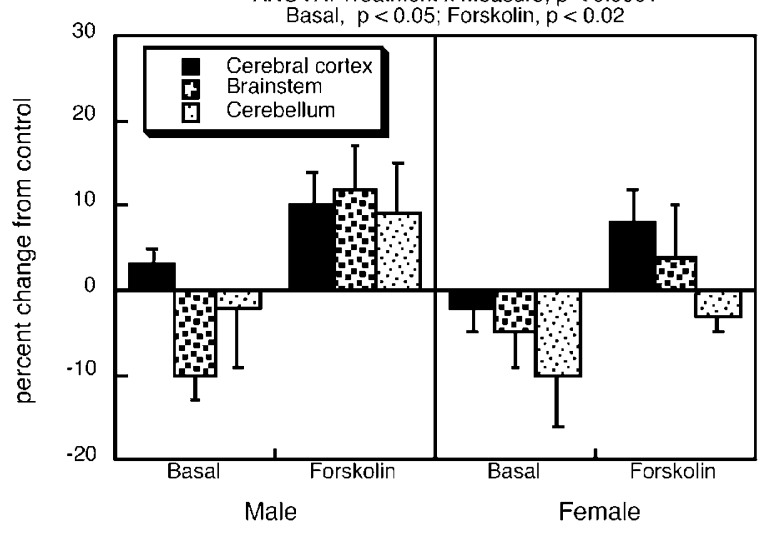
Prenatal and Adolescent Nicotine - Adenylyl Cyclase
ANOVA: Treatment, $p<0.0009 ;$ Treatment $x$ Measure, $p<0.0001$

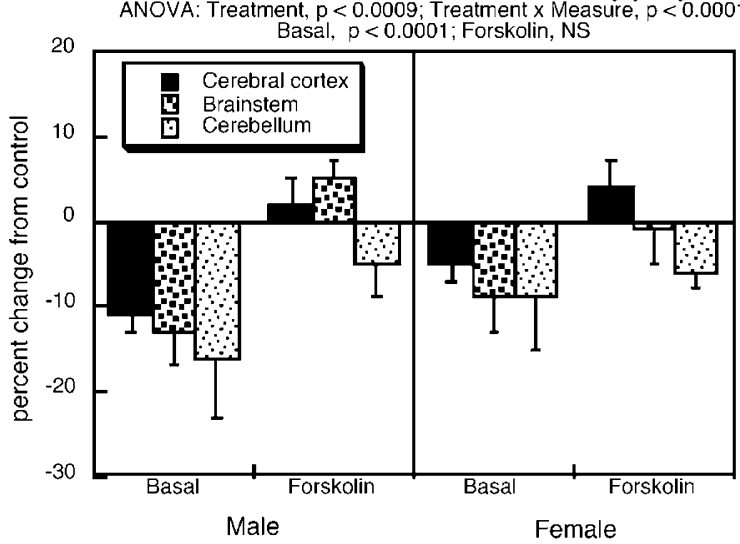

Figure 4 Effects of prenatal nicotine exposure (a), adolescent nicotine exposure (b), or prenatal nicotine followed by adolescent nicotine (c) on AC signaling. Data are shown as the percent change from the corresponding control values (Table I). ANOVA across all variables appears at the top of each panel. For prenatal nicotine, because of the treatment $x$ sex interaction, separate statistical analyses were conducted for males and females, shown at the bottom of (a); separate statistical evaluations were conducted for each measure but not for each region, in accordance with the appropriate interaction terms. For adolescent nicotine, lower order analysis for each measure appears at the top of the panel, without separation by sex or region, in keeping with the restriction of effects to a treatment $x$ measure interaction. Similarly, for the combined prenatal and adolescent treatment, the lower-order tests for each measure are shown at the top of the panel, as justified by the interaction of treatment measure but not sex or region. Abbreviation: NS, not significant. 


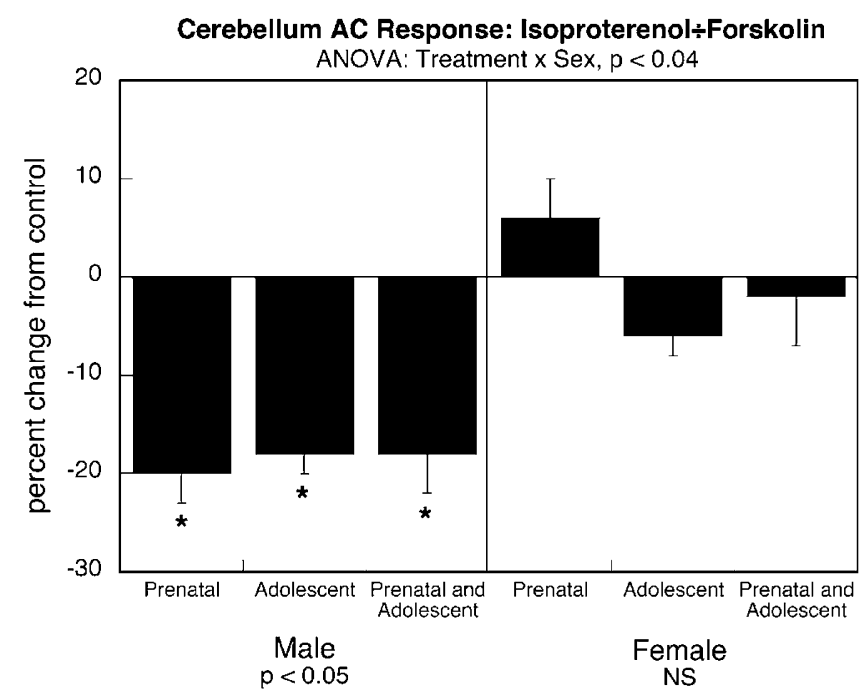

Figure 5 Effects of prenatal nicotine exposure, adolescent nicotine exposure, or prenatal nicotine followed by adolescent nicotine, on the response of cerebellar $A C$ activity to $\beta A R$ stimulation, evaluated as the ratio of activity in response to isoproterenol vs forskolin. Data are shown as the percent change from the corresponding control value (Table I). ANOVA across all variables appears at the top of the panel and asterisks denote individual values that differ significantly from the control. Abbreviation: NS, not significant.

\section{AC Signaling}

Across all variables, nicotine treatment elicited global, sex-dependent changes in AC activity (treatment $\times$ sex, $p<0.004)$ that differed between basal and forskolin-stimulated activity (treatment $\times$ measure, $p<0.0001$ ). With a twodimensional treatment design, the ANOVA also indicated the need to examine potentially non-additive interactions (prenatal nicotine $\times$ adolescent nicotine, $p<0.06$; prenatal nicotine $\times$ adolescent nicotine $\times$ measure, $p<0.1$ ).

Prenatal nicotine exposure led to an overall decrease in basal AC activity without a corresponding change in maximal activity evoked by forskolin (Figure 4a). As was true for ACh and 5HT biomarkers, males were affected significantly more than females. The long-term effects of adolescent nicotine exposure were less notable, with small but significant reductions in basal activity and elevations of the forskolin response, without sex preference (Figure $4 \mathrm{~b}$ ). Again, with combined prenatal and adolescent treatment, the effects looked quite similar to those of prenatal nicotine alone, with a significant reduction in basal activity without a corresponding change in the $\mathrm{AC}$ response to forskolin (Figure 4c).

To probe the mechanisms underlying the differences between the inhibitory effects on basal AC and the neutral or stimulatory effects on the forskolin response, we evaluated the ability of a $\beta \mathrm{AR}$ agonist, isoproterenol, to stimulate $\mathrm{AC}$ in the cerebellum. In control animals, isoproterenol was able to stimulate AC to approximately $20 \%$ of its maximal value, as assessed by the isoproterenol/ forskolin activity ratio (Table 1). Each of the three nicotine treatment paradigms interfered with the $\beta \mathrm{AR}$-mediated response, reducing the stimulation by about $20 \%$ relative to controls (Figure 5). Again, as with the basal AC measurements, the effects were restricted to males. To determine whether the loss of $\mathrm{AC}$ responsiveness reflected a decline in $\beta A R s$ as compared to uncoupling of the receptors from the response, we also evaluated $\beta \mathrm{AR}$ binding. There were no significant differences: males, $30 \pm 1 \mathrm{fmol} / \mathrm{mg}$ protein for controls, $31 \pm 1$ for prenatal nicotine, $29 \pm 1$ for adolescent nicotine, $30 \pm 1$ for combined treatment; females, $29 \pm 1$, $31 \pm 1,28 \pm 2$, and $29 \pm 1$, respectively.

\section{DISCUSSION}

Results of this study indicate that the effects of prenatal or adolescent nicotine exposure on brain development are indeed permanent, with a much more notable impact on synaptic activity and function than on indices of neural cell morphology. To relate our findings to earlier work, each of the treatments will be dealt with in turn.

\section{Prenatal Nicotine Exposure}

During the period of fetal nicotine exposure and continuing into early neonatal life, maternal nicotine treatment produces immediate deficits in the number of neural cells in a wide variety of brain regions, accompanied by perikaryal enlargement (swelling) that is typical of cell injury (Levin and Slotkin, 1998; Roy et al, 1998, 2002; Slotkin, 1992, 1998; Slotkin et al, 1987). Nevertheless, the number of neural cells eventually recovers and even becomes supranormal, with an elevated cell-packing density, largely because of reactive gliosis (Abdel-Rahman et al, 2003, 2004, 2005; Roy and Sabherwal, 1994, 1998; Roy et al, 2002); the same phenomenon occurs in the brains of children whose mothers smoked during pregnancy (Storm et al, 1999). Accordingly, by adolescence, many of the biochemical features of neuronal loss are absent, although detailed morphological examination reveals the underlying imbalances in neuron/glia ratios and in the density of the neuropil (Roy and Sabherwal, 1994, 1998; Roy et al, 2002). In keeping with this sequence, in the current study, we found only inconsistent changes in DNA-related biomarkers of cell number and packing density at 6 months of age, but nevertheless found a significant reduction in membrane complexity (subnormal membrane/total protein ratio), as would be expected from the deficiencies in neural connections as are apparent from morphologic examinations of the specific layers of the hippocampus and cerebral cortex (Roy and Sabherwal, 1994, 1998; Roy et al, 2002). Here, the biochemical approach is limited by the fact that each brain region is heterogeneous, so that relatively large changes in specific layers or subregions may be 'washed out' by the inclusion of larger amounts of unaffected areas. Obviously, detailed morphologic examination, such as that conducted in younger animals (Abdel-Rahman et al, 2003, 2004, 2005; Roy and Sabherwal, 1994, 1998; Roy et al, 2002), can resolve these issues. Nevertheless, our findings indicate that the permanence of the adverse effects of prenatal nicotine exposure are more readily demonstrated through indices of synaptic function than of neural cell number and size.

In earlier work, we showed that maternal nicotine administration results in biphasic deficits in ACh synaptic function in the offspring (Navarro et al, 1989; Slotkin, 1992, 1998, 1999, 2004; Zahalka et al, 1992): initial deficits in the 
early postnatal period are made up by weaning, only to reemerge in adolescence and young adulthood. In the current study, cerebrocortical ACh projections showed a persistence of these abnormalities at 6 months of age, evidenced by significant reductions in ChAT and HC3 binding; furthermore, synaptic activity, as monitored by the HC3/ChAT ratio, was severely subnormal. There are two noteworthy features to this pattern. First, the effects were not sustained in the hippocampus, a region in which deficits are prominent in adolescence and young adulthood (Zahalka et al, 1992); indeed, if anything, ACh biomarkers were increased in the hippocampus at 6 months. Second, the effects were far more substantial in males, a difference that first emerges in adolescence (Abreu-Villaça et al, $2004 \mathrm{~b})$. Both of these findings likely reflect the longterm plasticity of the brain, a feature that is particularly prominent for the hippocampus, a region in which neurogenesis continues throughout life (Brezun and Daszuta, 1999; Jacobs et al, 2000; McEwen, 2001). In this regard, it is especially important that both hippocampal neurogenesis and synaptic plasticity are controlled in large measure by estrogen receptors (McEwen, 2002; Tanapat et al, 1999), thus permitting greater adaptation in females. Nevertheless, the fact that there are ACh-related abnormalities in other brain regions of females is indicative that they are not totally spared the adverse, long-term effects of prenatal nicotine exposure, and as will be discussed later, prenatal nicotine sets the stage for enhancing the damage resulting from adolescent nicotine exposure in females. Finally, it is interesting to note that $\mathrm{nAChR}$ binding sites, the immediate target for nicotine, were largely unaffected at 6 months of age, echoing our earlier findings in adolescence and young adulthood (Abreu-Villaça et al, 2004b). Here again, these negative results do not rule out the possibility of significant changes in smaller subregions or for different $\mathrm{nAChR}$ subtypes (Chen et al, 2005; Tizabi and Perry, 2000), so that further examinations are warranted to see if these also persist throughout the lifespan.

The long-term effects of prenatal nicotine exposure on $5 \mathrm{HT}$ systems share many of the features noted for ACh pathways. Alterations in the expression of 5HT receptors were far more prominent in males than in females, and the constitutive marker for the integrity of 5HT terminals (5HT transporter) showed less effect than did the $5 \mathrm{HT}$ receptors. Here too, we found evidence for continuing plasticity in the response to the damage evoked by prenatal nicotine exposure: in adolescence, there are elevations in both cerebrocortical $5 \mathrm{HT}_{1 \mathrm{~A}}$ and $5 \mathrm{HT}_{2}$ receptors with the same pattern of sex preference (greater effects in males) (Slotkin et al, 2006), whereas at 6 months of age, we found reversal of the effects on the $5 \mathrm{HT}_{1 \mathrm{~A}}$ subtype. Again, although the maintained effect on $5 \mathrm{HT}_{2}$ receptors points out the permanence of $5 \mathrm{HT}$ abnormalities after prenatal nicotine exposure, the change in $5 \mathrm{HT}_{1 \mathrm{~A}}$ binding shows that specific indices and direction of change are not always sustained throughout the lifespan.

In our earlier work on AC signaling, we found transient elevations in maximal, forskolin-stimulated activity during adolescence, with a comparative deficiency in other AC measures, reflected either as smaller increases than for maximal activity, or as shifts to suppression of activity in response to neurotransmitter receptor activation (Slotkin et al, 1992, 2006). In the current study, by 6 months of age the transient elevation of forskolin-stimulated activity was no longer apparent, but the deficiencies in basal and neurotransmitter-stimulated activity remained. As with the other measures, males were affected more than females. Given the fact that AC is a signaling pathway common to multiple neurotransmitter and hormonal inputs, it is unlikely that the deficiencies seen here reflect a specific response to the abnormalities in $\mathrm{ACh}$ or $5 \mathrm{HT}$ input but rather represent a separable impact of prenatal nicotine exposure on the 'programming' of cellular responses. Indeed, our finding of deficient $\beta \mathrm{AR}$-mediated responses without a corresponding decrease in $\beta \mathrm{AR}$ binding reinforces the idea that these effects on cell signaling are mediated downstream from specific receptor inputs and are thus likely to be shared by a wider variety of receptors (ie 'heterologous' desensitization). Our findings suggest that the adverse effects will extend to far more neurotransmitter systems and circuits than those examined in the present study and future work needs to address the potential ubiquity of nicotine-induced anomalies of synaptic signaling and their behavioral correlates.

\section{Adolescent Nicotine Exposure}

Because many neurodevelopmental processes continue into young adulthood, the immediate effects of adolescent nicotine administration on biomarkers of neural cell number and size resemble those of fetal exposure, but with a much reduced impact (Abreu-Villaça et al, 2003c; Slotkin, 2002; Trauth et al, 2000b). Accordingly, in the present study, the only significant difference in these indices that remained detectable at 6 months of age was a decrease in the membrane/total protein ratio, just as was seen for prenatal nicotine. Nevertheless, the alterations for indices of synaptic function remained robust. Again, ACh systems showed persistent reductions in activity, as evidenced by reduced cerebrocortical ChAT and even greater deficits in HC3 binding. In fact, the effects were quite similar to those of prenatal nicotine exposure, including greater effects in males and elevations in other regions (hippocampus, midbrain), as with the prenatal nicotine regimen, there were no sustained changes in nAChR binding, which is not surprising, given that values return to normal within the first month of termination of adolescent nicotine exposure (Abreu-Villaça et al, 2003a, 2004b; Trauth et al, 2000a). These findings thus reinforce our earlier conclusions that the vulnerability of ACh systems to long-term deficits evoked by nicotine exposure persists from fetal stages all the way through adolescence, and is readily discernible as a deficiency in the indices of presynaptic activity (Abreu-Villaça et al, 2003a, 2004b; Trauth et al, 2000a).

In our earlier work for the short-term effects of adolescent nicotine exposure, we identified transient changes in the expression of 5HT receptors that were related to the immediate impact of nicotine treatment and subsequent withdrawal (Slotkin et al, 2006; Xu et al, 2001, 2002). Here, we examined the long-term consequences of the same treatment at 6 months of age and found significant increases in cerebrocortical $5 \mathrm{HT}_{1 \mathrm{~A}}$ and $5 \mathrm{HT}_{2}$ receptors, as well as for the 5HT transporter. The pattern bears similarities to the effects of prenatal nicotine in terms of 
regional selectivity (cerebral cortex $>$ brainstem) and sex preference (male $>$ female) but the persistent changes in $5 \mathrm{HT}_{1 \mathrm{~A}}$ receptors were opposite, decreased by prenatal nicotine but increased by adolescent nicotine. This suggests either a different regulatory adjustment from the two treatment paradigms, or alternatively that the changes with the adolescent exposure model might reflect a different underlying event, namely reactive sprouting consequent to the demonstrable 5HT nerve terminal damage (Xu et al, 2001). Although prenatal nicotine administration also damages 5HT projections to the cerebral cortex (Xu et al, 2001), the superior plasticity of the fetal/neonatal brain may permit greater subsequent recovery and therefore a different pattern of receptor and transporter changes. Here, detailed morphologic examinations would be required to establish the underlying events, but in any case, we would predict different behavioral consequences and/or 5HT drug reactivities of animals exposed to prenatal $v s$ adolescent nicotine.

Withdrawal after adolescent nicotine exposure is associated with an increase in forskolin-stimulated AC activity and a deficiency in basal or receptor-mediated activity relative to the maximum (Abreu-Villaça et al, 2003b; Slotkin et al, 2006; Xu et al, 2002). At 6 months, we found persistence of the same pattern: an elevated forskolin response unaccompanied by a corresponding increase in basal activity or in the response to $\beta$ AR stimulation. In fact, the latter two showed significant decreases relative to control. The net effect on cell signaling for adolescent nicotine exposure thus resembles that of prenatal nicotine and these alterations appear to be sustained throughout the lifespan. Again, we anticipate that these heterologous changes in cell signaling will be shared by multiple receptor inputs.

\section{Prenatal Nicotine Followed by Adolescent Nicotine}

Prenatal nicotine exposure has a far-reaching impact on the response to nicotine administered subsequently in adolescence (Abreu-Villaça et al, 2004a,b; Seidler et al, 1992; Slotkin et al, 2006). Although the prenatal treatment desensitizes nAChRs to the immediate effects of adolescent nicotine treatment, at the level of neural cell damage and loss and for indices of ACh synaptic activity, the effects are enhanced by the double treatment. In the current study, we found reductions in the membrane/total protein ratio at 6 months of age that were essentially indistinguishable from those seen with prenatal nicotine alone but the same was not the case for ACh biomarkers, where there was a clear enhancement by the combined exposure of adverse effects in females. In our earlier work on 5HT systems, we found that the immediate effects of adolescent nicotine administration and withdrawal were obtunded by prior, prenatal nicotine exposure, so that the net effects of the combined treatment looked quite similar to those seen in animals that had received the prenatal treatment alone (Slotkin et al, 2006). Here, at 6 months of age, we found the same pattern for 5HT systems in males, namely a virtually identical pattern for the combined exposure and for prenatal exposure alone. However, just as for ACh systems, females given the sequential treatment with prenatal and adolescent nicotine now showed enhanced vulnerability, evidenced by a substantial decrease in $5 \mathrm{HT}_{1 \mathrm{~A}}$ receptor binding. At the level of AC signaling, we again saw an impairment of basal activity and receptor-mediated responses relative to maximal activity, of the same magnitude as that seen with either prenatal or adolescent nicotine exposure alone, with preferential effects in males; as with the other synaptic markers, the net effect in males was not enhanced by the double treatment, so that essentially, either treatment alone produces the greatest possible deficit.

Putting these patterns together, we would anticipate that the net effects of combined treatment on synaptic function and related behaviors will likely have a greater impact on females than on males, even though males are more targeted by separate prenatal or adolescent nicotine exposure. Whereas females are largely spared the long-term neurochemical consequences of the individual effects, the sequential prenatal and adolescent exposure overcomes the sex-selective protective adaptations and neural plasticity that otherwise limit the consequences in females. Accordingly, although males are likely to show neurobehavioral deficits after any of the three exposure scenarios, in females, we expect that the combined exposure will produce greater effects than would be anticipated from the two separate exposures.

\section{Conclusion}

Our results indicate that prenatal nicotine exposure evokes permanent changes in indices of ACh and 5HT synaptic function that transcend the apparent recovery of lesssensitive indices of structural neural damage. Equally important, virtually the same effects occur with nicotine exposure in adolescence at plasma nicotine levels found in typical smokers, indicating that the vulnerability of the developing brain to nicotine extends into the stage where most smokers begin tobacco use. There are important ramifications to these findings. First, the fact that abnormalities extend beyond ACh systems, the immediate target of nicotine, to involve $5 \mathrm{HT}$ function provides a mechanistic underpinning for the epidemiological findings of greater susceptibility to affective, appetitive and sleep disorders in the offspring of women who smoke during pregnancy as well as in adolescent smokers (Oken et al, 2005; Patten et al, 2000; Salsberry and Reagan, 2005; Slikker and Schwetz, 2003; Toschke et al, 2003; Upadhyaya et al, 2002; Wu and Anthony, 1999). Notably, the fact that abnormalities extend to cell signaling cascades shared by multiple neurotransmitter inputs, also suggests that there will be an even wider spectrum of behavioral disorders as outcomes of either prenatal or adolescent nicotine exposure. Second, the greater effects of prenatal nicotine exposure in males correspond to their higher incidence of psychosocial sequelae such as learning and conduct disorders (Wakschlag and Hans, 2002; Wakschlag et al, 1997). At the same time, the fact that the relative protection of females disappears with the combined, sequential prenatal, and adolescent exposure points to a biological origin for the greater association for the effects of maternal smoking on the uptake and progression of adolescent tobacco use by their daughters (Kandel et al, 1994; Oncken et al, 2004; Roberts et al, 2005). Indeed, if our findings for combined prenatal and adolescent nicotine exposure in rats extend to 
adolescent smokers whose mothers smoked during pregnancy, there are a number of predictions that can be made that represent extensions of recent findings. First, there are individuals who are prone to the rapid onset of nicotine dependence, often after smoking only a few cigarettes, with a higher incidence of vulnerability in females (DiFranza et al, 2002a); we anticipate that this association will be even stronger for those whose mothers smoked during pregnancy. Second, we expect that the persistent changes seen here would render prenatally exposed adolescents especially vulnerable to relapse after attempts at smoking cessation (DiFranza and Wellman, 2005) and again, we predict this relationship will be selectively greater for women. Third, when adolescent smokers are abstinent, they show both cognitive impairment and depression (Colby et al, 2000; Goodman and Capitman, 2000; Hurt et al, 2000; Martini et al, 2002; Patten et al, 2000; Salin-Pascual et al, 1995; Tsoh et al, 2000; Wu and Anthony, 1999), problems that are worse in individuals who were exposed to nicotine in utero via maternal smoking (Oncken et al, 2004). Indeed, whereas adolescent smokers whose mothers did not smoke show cognitive improvement upon smoking cessation, those whose mothers did smoke show worsening of cognitive function during withdrawal (Jacobsen et al, 2005, 2006). Again, we expect that an examination of sex differences for this relationship will reveal a greater effect in females than males. Finally, given the targeting of 5HT systems for the lasting effects of prenatal or adolescent nicotine, alone or in combination, we would predict that treatments aimed at restoring $5 \mathrm{HT}$ function, such as serotonin-specific reuptake inhibitors, may be particularly useful in smoking cessation therapy for adolescent smokers, with the greatest effect seen in females whose mothers smoked during pregnancy.

Finally, our results address key issues in the persistence of nicotine addictability after both prenatal or adolescent nicotine exposure, either separately or together, and also account for the transgenerational nature of nicotine addiction, without requirement for underlying heritable characteristics. Nicotine exposure during either developmental period produced permanent changes in synaptic function, even after prolonged abstinence. These observations are entirely consistent with the view that the brain adaptations to addictive stimuli do not simply regress to normal after discontinuing drug exposure, but rather are kept in balance through lasting adjustments in synaptic activity, as postulated by the sensitization-homeostasis theory of nicotine addiction (DiFranza and Wellman, 2005). Accordingly, there are long-term sequelae that persist beyond the stage of smoking or abstinence, including enhanced susceptibility to relapse, and as found recently, emergence of depression as a consequence of adolescent smoking (Steuber and Danner, 2006). The current results, combined with earlier work on the prenatal + adolescent exposure model, permit the formulation of a hypothesis as to how smoking behaviors can be transmitted across generations (Figure 6). Prenatal nicotine exposure produces dysfunction in multiple neurotransmitter pathways, with the changes in cholinergic and serotonergic function contributing in major ways to abnormalities of cognition, reward, and affect (Slotkin, 1992, 1998, 1999, 2004). Importantly, many of these features emerge in adolescence (Navarro et al, 1989; Slotkin, 1992, 1998, 1999, 2004;

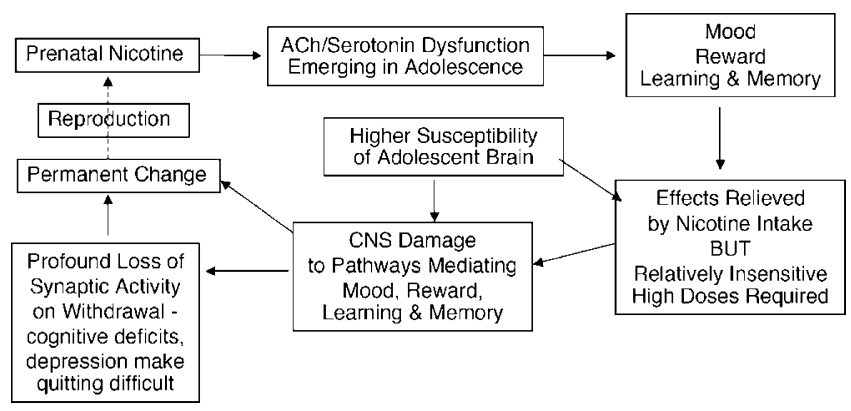

Figure 6 How prenatal nicotine exposure predisposes the brain to nicotine addiction in adolescence and leads to transgenerational effects (see text). Abbreviation: ACh, acetylcholine.

Zahalka et al, 1992), when access to tobacco products becomes available. At that stage, nicotine intake partially relieves the deficiencies; although the adolescent brain is highly responsive to nicotine (Abreu-Villaça et al, 2003a-c; Collins et al, 2004; Elliott et al, 2005; Faraday et al, 2001; Slotkin, 2002), prenatal nicotine exposure produces lasting desensitization (Abreu-Villaça et al, 2004b; Seidler et al, 1992), so that the offspring of smokers will tend toward much higher consumption to obtain the desired effect, which in turn extends and expands the degree of damage and reprogramming of neural circuits (Abreu-Villaça et al, 2004a), augmenting and cementing the permanent changes in synaptic function and behavioral performance. When these individuals attempt to quit, they are consequently thrown into a worsened degree of cognitive impairment, depression, and loss of reward than if they had never smoked at all, as revealed in recent findings (Jacobsen et al, 2006). These factors then render quitting smoking far less likely, enhancing the probability that this individual, too, will smoke through pregnancy, thus ensuring that the addictive cycle extends to the next generation. These conclusions make it all the more critical that public health focus on prevention of tobacco use during developmental stages ranging from pregnancy through adolescence, over and above efforts toward smoking cessation in current smokers.

\section{ACKNOWLEDGEMENTS}

This research was supported by a grant from Philip Morris, USA and Philip Morris International. The grantors did not have input into the experimental design or interpretation. The authors state that they have no conflicts of interest.

\section{REFERENCES}

Abdel-Rahman A, Dechkovskaia AM, Mehta-Simmons H, Guan S, Khan WA, Abou-Donia MB (2003). Increased expression of glial fibrillary acidic protein in cerebellum and hippocampus: differential effects on neonatal brain regional acetylcholinesterase following maternal exposure to combined chlorpyrifos and nicotine. J Toxicol Environ Health A 66: 2047-2066.

Abdel-Rahman A, Dechkovskaia AM, Mehta-Simmons H, Sutton JM, Guan X, Khan WA et al (2004). Maternal exposure to nicotine and chlorpyrifos, alone and in combination, leads to persistently elevated expression of glial fibrillary acidic protein 
in the cerebellum of the offspring in late puberty. Arch Toxicol 78: 467-476.

Abdel-Rahman A, Dechkovskaia AM, Sutton JM, Chen WC, Guan $\mathrm{X}$, Khan WA et al (2005). Maternal exposure of rats to nicotine via infusion during gestation produces neurobehavioral deficits and elevated expression of glial fibrillary acidic protein in the cerebellum and CA1 subfield in the offspring at puberty. Toxicology 209: 245-261.

Abreu-Villaça Y, Seidler FJ, Qiao D, Tate CA, Cousins MM, Thillai I et al (2003a). Short-term adolescent nicotine exposure has immediate and persistent effects on cholinergic systems: critical periods, patterns of exposure, dose thresholds. Neuropsychopharmacology 28: 1935-1949.

Abreu-Villaça Y, Seidler FJ, Slotkin TA (2003b). Impact of adolescent nicotine exposure on adenylyl cyclase-mediated cell signaling: enzyme induction, neurotransmitter-specific effects, regional selectivities, and the role of withdrawal. Brain Res 988: 164-172.

Abreu-Villaça Y, Seidler FJ, Slotkin TA (2004a). Does prenatal nicotine sensitize the brain to nicotine-induced neurotoxicity in adolescence? Neuropsychopharmacology 29: 1440-1450.

Abreu-Villaça Y, Seidler FJ, Tate CA, Cousins MM, Slotkin TA (2004b). Prenatal nicotine exposure alters the response to nicotine administration in adolescence: effects on cholinergic systems during exposure and withdrawal. Neuropsychopharmaco$\log y$ 29: 879-890.

Abreu-Villaça Y, Seidler FJ, Tate CA, Slotkin TA (2003c). Nicotine is a neurotoxin in the adolescent brain: critical periods, patterns of exposure, regional selectivity, and dose thresholds for macromolecular alterations. Brain Res 979: 114-128.

Altman J, Bayer SA (1990). Migration and distribution of two populations of hippocampal granule cell precursors during the perinatal and postnatal periods. J Comp Neurol 301: 365-381.

Arango V, Underwood MD, Boldrini M, Tamir H, Kassir SA, Hsiung $S$ et al (2001). Serotonin-1A receptors, serotonin transporter binding and serotonin transporter mRNA expression in the brainstem of depressed suicide victims. Neuropsychopharmacology 25: 892-903.

Aubert I, Cecyre D, Gauthier S, Quirion R (1996). Comparative ontogenic profile of cholinergic markers, including nicotinic and muscarinic receptors, in the rat brain. J Comp Neurol 369: 31-55.

Auman JT, Seidler FJ, Slotkin TA (2000). Neonatal chlorpyrifos exposure targets multiple proteins governing the hepatic adenylyl cyclase signaling cascade: implications for neurotoxicity. Dev Brain Res 121: 19-27.

Auman JT, Seidler FJ, Slotkin TA (2001). Regulation of fetal cardiac and hepatic $\beta$-adrenoceptors and adenylyl cyclase signaling: terbutaline effects. Am J Physiol 281: R1079-R1089.

Barnes NM, Sharp T (1999). A review of central 5-HT receptors and their function. Neuropharmacology 38: 1083-1152.

Bayer SA (1983). [ $\left.{ }^{3} \mathrm{H}\right]$ Thymidine-radiographic studies of neurogenesis in the rat olfactory bulb. Exp Brain Res 50: 329-340.

Bayer SA, Yackel JW, Puri PS (1982). Neurons in the rat dentate gyrus granular layer substantially increase during juvenile and adult life. Science 216: 890-892.

Bell JM, Whitmore WL, Queen KL, Orband-Miller L, Slotkin TA (1987). Biochemical determinants of growth sparing during neonatal nutritional deprivation or enhancement: ornithine decarboxylase, polyamines, and macromolecules in brain regions and heart. Pediatr Res 22: 599-604.

Brezun JM, Daszuta A (1999). Depletion in serotonin decreases neurogenesis in the dentate gyrus and the subventricular zone of adult rats. Neuroscience 89: 999-1002.

Chen H, Parker SL, Matta SG, Sharp BM (2005). Gestational nicotine exposure reduces nicotinic cholinergic receptor (nAChR) expression in dopaminergic brain regions of adolescent rats. Eur J Neurosci 22: 380-388.
Colby SM, Tiffany ST, Shiffman S, Niaura RS (2000). Are adolescent smokers dependent on nicotine? A review of the evidence. Drug Alc Depend 59: S83-S95.

Collins SL, Wade D, Ledon J, Izenwasser S (2004). Neurochemical alterations produced by daily nicotine exposure in periadolescent $v s$ adult male rats. Eur J Pharmacol 502: 75-85.

DiFranza J, Savageau JA, Rigotti NA, Fletcher K, Ockene JK, McNeill AD et al (2002a). Development of symptoms of tobacco dependence in youths: 30-month follow-up data from the DANDY study. Tob Control 11: 228-235.

DiFranza JR, Rigotti NA, McNeill AD, Ockene JK, Savageau JA, St Cyr D et al (2000). Initial symptoms of nicotine dependence in adolescents. Tob Control 9: 313-319.

DiFranza JR, Savageau JA, Fletcher K, Ockene JK, Rigotti NA, McNeill AD et al (2002b). Measuring the loss of autonomy over nicotine use in adolescents: the DANDY (development and assessment of nicotine dependence in youths) study. Arch Pediatr Adolesc Med 156: 397-403.

DiFranza JR, Wellman RJ (2005). A sensitization-homeostasis model of nicotine craving, withdrawal, and tolerance: integrating the clinical and basic science literature. Nicotine Tob Res 7: 9-26.

Elliott BM, Faraday MM, Phillips JM, Grunberg NE (2005). Adolescent and adult female rats differ in sensitivity to nicotine's activity effects. Pharmacol Biochem Behav 80: 567-575.

Ernst M, Moolchan ET, Robinson ML (2001). Behavioral and neural consequences of prenatal exposure to nicotine. J Am Acad Child Adolesc Psychiatry 40: 630-641.

Faraday MM, Elliott BM, Grunberg NE (2001). Adult vs adolescent rats differ in biobehavioral responses to chronic nicotine administration. Pharmacol Biochem Behav 70: 475-489.

Flores CM, Rogers SW, Pabreza LA, Wolfe BB, Kellar KJ (1992). A subtype of nicotinic cholinergic receptor in rat brain is composed of alpha4 and beta2 subunits and is up-regulated by chronic nicotine treatment. Mol Pharmacol 41: 31-37.

Fujita M, Charney DS, Innis RB (2000). Imaging serotonergic neurotransmission in depression: hippocampal pathophysiology may mirror global brain alterations. Biol Psychiatr 48: 801-812.

Goodman E, Capitman J (2000). Depressive symptoms and cigarette smoking among teens. Pediatrics 106: 748-755.

Grote HE, Bull ND, Howard ML, van Dellen A, Blakemore C, Bartlett PF et al (2005). Cognitive disorders and neurogenesis deficits in Huntington's disease mice are rescued by fluoxetine. Eur J Neurosci 22: 2081-2088.

Happe HK, Murrin LC (1992). High-affinity choline transport regulation by drug administration during postnatal development. J Neurochem 58: 2053-2059.

Hellstrom-Lindahl E, Nordberg A (2002). Smoking during pregnancy: a way to transfer the addiction to the next generation? Respiration 69: 289-293.

Hurt RD, Croghan GA, Beede SD, Wolter TD, Croghan IT, Patten CA (2000). Nicotine patch therapy in 101 adolescent smokers: efficacy, withdrawal symptom relief, and carbon monoxide and plasma cotinine levels. Arch Pediatr Adolesc Med 154: 31-37.

Huttenlocher PR (1990). Morphometric study of human cerebral cortex development. Neuropsychologia 28: 517-527.

Isaac PF, Rand MJ (1972). Cigarette smoking and plasma levels of nicotine. Nature 236: 308-310.

Jacobs BL, van Praag H, Gage FH (2000). Adult brain neurogenesis and psychiatry: a novel theory of depression. Mol Psychiatry 5: 262-269.

Jacobsen LK, Krystal JH, Mencl WE, Westerveld M, Frost SJ, Pugh KR (2005). Effects of smoking and smoking abstinence on cognition in adolescent tobacco smokers. Biol Psychiatry 57: $56-66$.

Jacobsen LK, Slotkin TA, Westerveld M, Mencl WE, Pugh KR (2006). Visuospatial memory deficits during nicotine withdrawal in adolescents with prenatal exposure to active maternal smoking. Neuropsychopharmacology 31: 1550-1561. 
Kandel DB, Wu P, Davies M (1994). Maternal smoking during pregnancy and smoking by adolescent daughters. Am J Public Health 84: 1407-1413.

Klemm N, Kuhar MJ (1979). Post-mortem changes in high affinity choline uptake. J Neurochem 32: 1487-1494.

Labarca C, Piagen K (1980). A simple, rapid, and sensitive DNA assay procedure. Anal Biochem 102: 344-352.

Lau C, Seidler FJ, Cameron AM, Navarro HA, Bell JM, Bartolome J et al (1988). Nutritional influences on adrenal chromaffin cell development: comparison with central neurons. Pediatr Res 24: 583-587.

Levin ED, Slotkin TA (1998). Developmental neurotoxicity of nicotine. In: Slikker W, Chang LW (eds). Handbook of Developmental Neurotoxicology. Academic Press: San Diego. pp 587-615.

Leysen JE, Niemegeers CJ, Van Nueten JM, Laduron PM (1982). $\left[{ }^{3} \mathrm{H}\right]$ Ketanserin (R41468), a selective ${ }^{3} \mathrm{H}$-ligand for serotonin ${ }_{2}$ receptor binding sites: binding properties, brain distribution, and functional role. Mol Pharmacol 21: 301-314.

Lichtensteiger W, Ribary U, Schlumpf M, Odermatt B, Widmer HR (1988). Prenatal adverse effects of nicotine on the developing brain. Prog Brain Res 73: 137-157.

Limbird LE, Macmillan ST (1981). Mn-uncoupling of the catecholamine sensitive adenylate cyclase system of rat reticulocytes. Biochim Biophys Acta 677: 408-416.

Luck W, Nau H, Hansen R, Steldinger R (1985). Extent of nicotine and cotinine transfer to the human fetus, placenta and amniotic fluid of smoking mothers. Dev Pharmacol Ther 8: 384-395.

Maes M, Meltzer H (1995). The serotonin hypothesis of major depression. In: Bloom FE, Kupfer DJ, Bunney BS, Ciaranello RD, Davis KL, Koob GF et al (eds). Psychopharmacology: The Fourth Generation of Progress. Raven Press: New York. pp 933-944.

Martini S, Wagner FA, Anthony JC (2002). The association of tobacco smoking and depression in adolescence: evidence from the United States. Subst Use Misuse 37: 1853-1867.

McEwen BS (2001). Plasticity of the hippocampus: adaptation to chronic stress and allostatic load. Ann NY Acad Sci 933: 265-277.

McEwen BS (2002). Sex, stress and the hippocampus: allostasis, allostatic load and the aging process. Neurobiol Aging 23: 921-939.

McWilliams JR, Lynch G (1983). Rate of synaptic replacement in denervated rat hippocampus declines precipitously from the juvenile period to adulthood. Science 221: 572-574.

Moret C, Briley M (1991). Platelet ${ }^{3} \mathrm{H}$-paroxetine binding to the serotonin transporter is insensitive to changes in central serotonergic innervation in the rat. Psychiatr Res 38: 97-104.

Morin D, Sapena R, Zini R, Tillement JP (1992). Serotonin enhances the $\beta$-adrenergic response in rat brain cortical slices. Eur J Pharmacol 225: 273-274.

Muneoka K, Ogawa T, Kamei K, Mimura Y, Kato H, Takigawa M (2001). Nicotine exposure during pregnancy is a factor which influences serotonin transporter density in the rat brain. Eur $J$ Pharmacol 411: 279-282.

Murrin LC, Ferrer JR, Zeng W (1985). Nicotine administration during pregnancy and its effect on striatal development. Neurosci Abs 11: 69.

Navarro HA, Seidler FJ, Eylers JP, Baker FE, Dobbins SS, Lappi SE et al (1989). Effects of prenatal nicotine exposure on development of central and peripheral cholinergic neurotransmitter systems. Evidence for cholinergic trophic influences in developing brain. J Pharmacol Exp Ther 251: 894-900.

Nemeroff CB (1998). The neurobiology of depression. Sci Am 278: 42-49.

Niaura R, Bock B, Lloyd EE, Brown R, Lipsitt LP, Buka S (2001). Maternal transmission of nicotine dependence: psychiatric, neurocognitive and prenatal factors. Am J Addict 10: 16-29.

Nutt DJ (2002). The neuropharmacology of serotonin and noradrenaline in depression. Int Clin Psychopharmacol 17: S1-S12.
Oken E, Huh SY, Taveras EM, Rich-Edwards JW, Gillman MW (2005). Associations of maternal prenatal smoking with child adiposity and blood pressure. Obes Res 13: 2021-2028.

Oncken C, McKee S, Krishnan-Sarin S, O'Malley S, Mazure C (2004). Gender effects of reported in utero tobacco exposure on smoking initiation, progression and nicotine dependence in adult offspring. Nicotine Tobacco Res 6: 829-833.

Park S, Harrold JA, Widdowson PS, Williams G (1999). Increased binding at $5-\mathrm{HT}_{1 \mathrm{~A}}, 5-\mathrm{HT}_{1 \mathrm{~B}}$, and $5-\mathrm{HT}_{2 \mathrm{~A}}$ receptors and $5-\mathrm{HT}$ transporters in diet-induced obese rats. Brain Res 847: 90-97.

Patten CA, Choi WS, Gillin JC, Pierce JP (2000). Depressive symptoms and cigarette smoking predict development and persistence of sleep problems in US adolescents. Pediatrics 106: 50-58.

Porath AJ, Fried PA (2005). Effects of prenatal cigarette and marijuana exposure on drug use among offspring. Neurotoxicol Teratol 27: 267-277.

Qiao D, Seidler FJ, Abreu-Villaça Y, Tate CA, Cousins MM, Slotkin TA (2004). Chlorpyrifos exposure during neurulation: cholinergic synaptic dysfunction and cellular alterations in brain regions at adolescence and adulthood. Dev Brain Res 148: 43-52.

Qiao D, Seidler FJ, Tate CA, Cousins MM, Slotkin TA (2003). Fetal chlorpyrifos exposure: adverse effects on brain cell development and cholinergic biomarkers emerge postnatally and continue into adolescence and adulthood. Environ Health Perspect 111: 536-544.

Ribary U, Lichtensteiger W (1989). Effects of acute and chronic prenatal nicotine treatment on central catecholamine systems of male and female rat fetuses and offspring. J Pharmacol Exp Ther 248: 786-792.

Roberts KH, Munaf MR, Rodriguez D, Drury M, Murphy MFG, Neale RE et al (2005). Longitudinal analysis of the effect of prenatal nicotine exposure on subsequent smoking behavior of offspring. Nicotine Tob Res 7: 801-808.

Rovescalli AC, Brunello N, Perez J, Vitali S, Steardo L, Racagni G (1993). Heterologous sensitization of adenylate cyclase activity by serotonin in the rat cerebral cortex. Eur Neuropsychopharmacol 3: 463-475.

Roy TS, Andrews JE, Seidler FJ, Slotkin TA (1998). Nicotine evokes cell death in embryonic rat brain during neurulation. J Pharmacol Exp Ther 287: 1135-1144.

Roy TS, Sabherwal U (1994). Effects of prenatal nicotine exposure on the morphogenesis of somatosensory cortex. Neurotoxicol Teratol 16: 411-421.

Roy TS, Sabherwal U (1998). Effects of gestational nicotine exposure on hippocampal morphology. Neurotoxicol Teratol 20: $465-473$.

Roy TS, Seidler FJ, Slotkin TA (2002). Prenatal nicotine exposure evokes alterations of cell structure in hippocampus and somatosensory cortex. J Pharmacol Exp Ther 300: 124-133.

Salin-Pascual RJ, De la Fuente JR, Galicia-Polo L, Drucker-Colin R (1995). Effects of transdermal nicotine on mood and sleep in nonsmoking major depressed patients. Psychopharmacology 121: 476-479.

Salsberry PJ, Reagan PB (2005). Dynamics of early childhood overweight. Pediatrics 116: 1329-1338.

Sarasin A, Schlumpf M, Müller M, Fleischmann I, Lauber ME, Lichtensteiger W (2003). Adrenal-mediated rather than direct effects of nicotine as a basis of altered sex steroid synthesis in fetal and neonatal rat. Reprod Toxicol 17: 153-162.

Scheetz AJ, Constantine-Paton M (1994). Modulation of NMDA receptor function: implications for vertebrate neural development. FASEB J 8: 745-752.

Seamon KB, Daly JW (1986). Forskolin: its biological and chemical properties. Adv Cyclic Nucleotide Protein Phosphorylation Res 20: $1-150$.

Seidler FJ, Levin ED, Lappi SE, Slotkin TA (1992). Fetal nicotine exposure ablates the ability of postnatal nicotine challenge to 
release norepinephrine from rat brain regions. Dev Brain Res 69: 288-291.

Simon JR, Atweh S, Kuhar MJ (1976). Sodium-dependent high affinity choline uptake: a regulatory step in the synthesis of acetylcholine. J Neurochem 26: 909-922.

Slikker W, Schwetz BA (2003). Childhood obesity: the possible role of maternal smoking and impact on public health. J Child Health 1: $29-40$

Slikker W, Xu ZA, Levin ED, Slotkin TA (2005). Mode of action: disruption of brain cell replication, second messenger, and neurotransmitter systems during development leading to cognitive dysfunction-developmental neurotoxicity of nicotine. Crit Rev Toxicol 35: 703-711.

Slotkin TA (1992). Prenatal exposure to nicotine: what can we learn from animal models? In: Zagon IS, Slotkin TA (eds). Maternal Substance Abuse and the Developing Nervous System. Academic Press: San Diego. pp 97-124.

Slotkin TA (1998). Fetal nicotine or cocaine exposure: which one is worse? J Pharmacol Exp Ther 285: 931-945.

Slotkin TA (1999). Developmental cholinotoxicants: nicotine and chlorpyrifos. Environ Health Perspect 107(Suppl 1): 71-80.

Slotkin TA (2002). Nicotine and the adolescent brain: insights from an animal model. Neurotoxicol Teratol 24: 369-384.

Slotkin TA (2004). Cholinergic systems in brain development and disruption by neurotoxicants: nicotine, environmental tobacco smoke, organophosphates. Toxicol Appl Pharmacol 198: $132-151$.

Slotkin TA, McCook EC, Lappi SE, Seidler FJ (1992). Altered development of basal and forskolin-stimulated adenylate cyclase activity in brain regions of rats exposed to nicotine prenatally. Dev Brain Res 68: 233-239.

Slotkin TA, McCook EC, Ritchie JC, Carroll BJ, Seidler FJ (1997). Serotonin transporter expression in rat brain regions and blood platelets: aging and glucocorticoid effects. Biol Psychiatry 41: 172-183.

Slotkin TA, Miller DB, Fumagalli F, McCook EC, Zhang J, Bissette $G$ et al (1999). Modeling geriatric depression in animals: biochemical and behavioral effects of olfactory bulbectomy in young versus aged rats. J Pharmacol Exp Ther 289: 334-345.

Slotkin TA, Orband-Miller L, Queen KL, Whitmore WL, Seidler FJ (1987). Effects of prenatal nicotine exposure on biochemical development of rat brain regions: maternal drug infusions via osmotic minipumps. J Pharmacol Exp Ther 240: 602-611.

Slotkin TA, Persons D, Slepetis RJ, Taylor D, Bartolome J (1984). Control of nucleic acid and protein synthesis in developing brain, kidney, and heart of the neonatal rat: effects of $\alpha$ difluoromethylornithine, a specific, irreversible inhibitor of ornithine decarboxylase. Teratology 30: 211-224.

Slotkin TA, Seidler FJ, Ali SF (2000). Cellular determinants of reduced adaptability of the aging brain: neurotransmitter utilization and cell signaling responses after MDMA lesions. Brain Res 879: 163-173.

Slotkin TA, Seidler FJ, Crain BJ, Bell JM, Bissette G, Nemeroff CB (1990). Regulatory changes in presynaptic cholinergic function assessed in rapid autopsy material from patients with Alzheimer disease: implications for etiology and therapy. Proc Natl Acad Sci USA 87: 2452-2455.

Slotkin TA, Seidler FJ, Qiao D, Aldridge JE, Tate CA, Cousins MM et al (2005). Effects of prenatal nicotine exposure on primate brain development and attempted amelioration with supplemental choline or vitamin C: neurotransmitter receptors, cell signaling and cell development biomarkers in fetal brain regions of Rhesus monkeys. Neuropsychopharmacology 30: $129-144$.

Slotkin TA, Tate CA, Cousins MM, Seidler FJ (2006). Prenatal nicotine exposure alters the response to subsequent nicotine administration and withdrawal in adolescence: serotonin receptors and cell signaling. Neuropsychopharmacology 31: 2462-2475.
Smith PK, Krohn RI, Hermanson GT, Mallia AK, Gartner FH, Provenzano MD et al (1985). Measurement of protein using bicinchoninic acid. Anal Biochem 150: 76-85.

Snedecor GW, Cochran WG (1967). Statistical Methods. Iowa State University Press: Ames, Iowa. 593pp.

Spear LP (2000). The adolescent brain and age-related behavioral manifestations. Neurosci Biobehav Rev 24: 417-463.

Steuber TL, Danner FW (2006). Adolescent smoking and depression: which comes first? Addict Behav 31: 133-136.

Stockmeier CA, Shapiro LA, Dilley GE, Kolli TN, Friedman L, Rajkowska G (1998). Increase in serotonin-1A autoreceptors in the midbrain of suicide victims with major depression: postmortem evidence for decreased serotonin activity. J Neurosci 18: 7394-7401.

Storm H, Nylander G, Saugstad OD (1999). The amount of brainstem gliosis in sudden infant death syndrome (SIDS) victims correlates with maternal cigarette smoking during pregnancy. Acta Paediatry 88: 13-18.

Tanapat P, Hastings NB, Reeves AJ, Gould E (1999). Estrogen stimulates a transient increase in the number of new neurons in the dentate gyrus of the adult female rat. $J$ Neurosci 19: $5792-5801$

Tizabi Y, Perry DC (2000). Prenatal nicotine exposure is associated with an increase in [ $\left.{ }^{125} \mathrm{I}\right]$ epibatidine binding in discrete cortical regions in rats. Pharmacol Biochem Behav 67: 319-323.

Toschke AM, Ehlin AG, von Kries R, Ekbom A, Montgomery SM (2003). Maternal smoking during pregnancy and appetite control in offspring. J Perinat Med 31: 251-256.

Trauth JA, McCook EC, Seidler FJ, Slotkin TA (2000a). Modeling adolescent nicotine exposure: effects on cholinergic systems in rat brain regions. Brain Res 873: 18-25.

Trauth JA, Seidler FJ, McCook EC, Slotkin TA (1999a). Adolescent nicotine exposure causes persistent upregulation of nicotinic cholinergic receptors in rat brain regions. Brain Res 851: 9-19.

Trauth JA, Seidler FJ, McCook EC, Slotkin TA (1999b). Adolescent nicotine exposure causes persistent upregulation of nicotinic cholinergic receptors in rat brain regions. Brain Res 851: 9-19.

Trauth JA, Seidler FJ, Slotkin TA (2000b). An animal model of adolescent nicotine exposure: effects on gene expression and macromolecular constituents in rat brain regions. Brain Res 867: 29-39.

Tsoh JY, Humfleet GL, Munoz RF, Reus VI, Hartz DT, Hall SM (2000). Development of major depression after treatment for smoking cessation. Am J Psychiatry 157: 368-374.

Upadhyaya HP, Deas D, Brady KT, Kruesi M (2002). Cigarette smoking and psychiatric comorbidity in children and adolescents. J Am Acad Child Adolesc Psychiatry 41: 1294-1305.

Vickroy T, Roeske W, Yamamura H (1984). Sodium-dependent high-affinity binding of $\left[{ }^{3} \mathrm{H}\right]$ hemicholinium-3 in the rat brain: a potentially selective marker for presynaptic cholinergic sites. Life Sci 35: 2335-2343.

Wakschlag LS, Hans SL (2002). Maternal smoking during pregnancy and conduct problems in high-risk youth: a developmental framework. Dev Psychopathol 14: 351-369.

Wakschlag LS, Lahey BB, Loeber R, Green SM, Gordon RA, Leventhal BL (1997). Maternal smoking during pregnancy and the risk of conduct disorder in boys. Arch Gen Psychiatry 54: 670-676.

Wakschlag LS, Pickett KE, Cook E, Benowitz NL, Leventhal BL (2002). Maternal smoking during pregnancy and severe antisocial behavior in offspring: a review. Am J Public Health 92: 966-974.

Weissman MM, Warner V, Wickramaratne PJ, Kandel DB (1999). Maternal smoking during pregnancy and psychopathology in offspring followed to adulthood. $\mathrm{J} \mathrm{Am}$ Acad Child Adolesc Psychiatry 38: 892-899.

Weitzman M, Byrd RS, Aligne CA, Moss M (2002). The effects of tobacco exposure on children's behavioral and cognitive 
functioning: implications for clinical and public health policy and future research. Neurotoxicol Teratol 24: 397-406.

Winick M, Noble A (1965). Quantitative changes in DNA, RNA and protein during prenatal and postnatal growth in the rat. Dev Biol 12: 451-466.

Wu LT, Anthony JC (1999). Tobacco smoking and depressed mood in late childhood and early adolescence. Am J Public Health 89: 1837-1840.

Xu Z, Seidler FJ, Ali SF, Slikker W, Slotkin TA (2001). Fetal and adolescent nicotine administration: effects on CNS serotonergic systems. Brain Res 914: 166-178.

Xu Z, Seidler FJ, Cousins MM, Slikker W, Slotkin TA (2002). Adolescent nicotine administration alters serotonin receptors and cell signaling mediated through adenylyl cyclase. Brain Res 951: 280-292.

Yatham LN, Liddle PF, Dennie J, Shiah IS, Adam MJ, Lane CJ et al (1999). Decrease in brain serotonin-2 receptor binding in patients with major depression following desipramine treatment: a positron emission tomography study with fluorine-18-labeled setoperone. Arch Gen Psychiatry 56: 705-711.

Yatham LN, Liddle PF, Shiah IS, Scarrow G, Lam RW, Adam MJ et al (2000). Brain serotonin-2 receptors in major depression: a positron emission tomography study. Arch Gen Psychiatry 57: 850-858.
Zahalka EA, Seidler FJ, Lappi SE, McCook EC, Yanai J, Slotkin TA (1992). Deficits in development of central cholinergic pathways caused by fetal nicotine exposure: differential effects on choline acetyltransferase activity and $\left[{ }^{3} \mathrm{H}\right]$ hemicholinium-3 binding. Neurotoxicol Teratol 14: 375-382.

Zahalka EA, Seidler FJ, Lappi SE, Yanai J, Slotkin TA (1993). Differential development of cholinergic nerve terminal markers in rat brain regions: implications for nerve terminal density, impulse activity and specific gene expression. Brain Res 601: 221-229.

Zeiders JL, Seidler FJ, Iaccarino G, Koch WJ, Slotkin TA (1999). Ontogeny of cardiac $\beta$-adrenoceptor desensitization mechanisms: agonist treatment enhances receptor/G-protein transduction rather than eliciting uncoupling. J Mol Cell Cardiol 31: 413-423.

Zeiders JL, Seidler FJ, Slotkin TA (1997). Ontogeny of regulatory mechanisms for $\beta$-adrenoceptor control of rat cardiac adenylyl cyclase: targeting of G-proteins and the cyclase catalytic subunit. J Mol Cell Cardiol 29: 603-615.

Zhu J, Taniguchi T, Tanaka T, Suzuki F, Muramatsu I (2000). Effects of perinatal nicotine exposure on development of $\left[{ }^{3} \mathrm{H}\right]$ hemicholinium-3 binding sites in rat neonate brain. Jpn $\mathrm{J}$ Pharmacol 84: 32-35. 